\title{
Mouse models of atherosclerosis and their suitability for the study of myocardial infarction
}

\author{
Pelin Golforoush ${ }^{1}$. Derek M. Yellon ${ }^{1} \cdot$ Sean M. Davidson ${ }^{1}$ (D)
}

Received: 31 July 2020 / Accepted: 28 October 2020 / Published online: 30 November 2020

(c) The Author(s) 2020

\begin{abstract}
Atherosclerotic plaques impair vascular function and can lead to arterial obstruction and tissue ischaemia. Rupture of an atherosclerotic plaque within a coronary artery can result in an acute myocardial infarction, which is responsible for significant morbidity and mortality worldwide. Prompt reperfusion can salvage some of the ischaemic territory, but ischaemia and reperfusion (IR) still causes substantial injury and is, therefore, a therapeutic target for further infarct limitation. Numerous cardioprotective strategies have been identified that can limit IR injury in animal models, but none have yet been translated effectively to patients. This disconnect prompts an urgent re-examination of the experimental models used to study IR. Since coronary atherosclerosis is the most prevalent morbidity in this patient population, and impairs coronary vessel function, it is potentially a major confounder in cardioprotective studies. Surprisingly, most studies suggest that atherosclerosis does not have a major impact on cardioprotection in mouse models. However, a major limitation of atherosclerotic animal models is that the plaques usually manifest in the aorta and proximal great vessels, and rarely in the coronary vessels. In this review, we examine the commonly used mouse models of atherosclerosis and their effect on coronary artery function and infarct size. We conclude that none of the commonly used strains of mice are ideal for this purpose; however, more recently developed mouse models of atherosclerosis fulfil the requirement for coronary artery lesions, plaque rupture and lipoprotein patterns resembling the human profile, and may enable the identification of therapeutic interventions more applicable in the clinical setting.
\end{abstract}

Keywords Atherosclerosis $\cdot$ Ischaemia $\cdot$ Reperfusion $\cdot$ Cardioprotection $\cdot$ Myocardial infarction $\cdot$ Mice $\cdot$ Coronary artery $\cdot$ Vascular function

\section{Introduction}

\section{Myocardial infarction and protection from ischaemia/reperfusion injury}

Cardiovascular disease (CVD) is the leading cause of mortality worldwide, accounting for an estimated 17.9 million deaths annually, representing $31 \%$ of all global deaths [149]. Four out of five CVD associated deaths are caused by myocardial infarction (MI) and ischaemic stroke [149]. These figures show there is an immediate need for appropriate interventions to improve survival and prognosis for CVD patients.

Sean M. Davidson

s.davidson@ucl.ac.uk

1 The Hatter Cardiovascular Institute, 67 Chenies Mews, London WC1E 6HX, UK
MI is caused by obstruction of blood flow through one of the major coronary arteries supplying the myocardium, usually due to atherosclerotic plaque rupture and thrombosis. Prolonged ischaemia results in oncotic, necrotic, apoptotic and necroptotic death of heart muscle $[31,45,96,103]$. The extent of cell death (infarct size) depends crucially on the duration of ischaemia, the size of the ischaemic area or area at risk (AAR), the degree of coronary collateral blood flow and the extent of coronary microvascular dysfunction [14, 71]. In order to salvage the ischaemic myocardium at risk of death, the tissue must be reperfused as soon as possible. Current strategies of intervention for acute ST-segment-elevation MI (STEMI) are based on opening occluded arteries using percutaneous coronary intervention or thrombolysis, or bypassing the occluded arteries by coronary artery bypass surgery $(\mathrm{CABG})$. Nonetheless, reperfusion itself triggers several damaging processes leading to myocardial injury due to oxidative stress, cytosolic and mitochondrial calcium 
overload, rapid restoration of intracellular $\mathrm{pH}$, opening of the mitochondrial permeability transition pore (MPTP) leading to the release of cytochrome $\mathrm{c}$ and induction of apoptosis, gap junction changes and inflammation [71]. Mitochondrial outer membrane permeabilisation (MOMP) leads to the re-localisation of cytochrome $\mathrm{c}$ from mitochondria to the cytosol, where it initiates apoptosome formation and caspase activation [151]. In addition, reperfusion leads to vascular injury including impaired vasomotion and capillary destruction which contribute to microvascular obstruction (MVO) and lack of reflow [74]. Consequently, the attempt to salvage the myocardium can, itself, cause a degree of irreversible injury and cell death, which is referred to as reperfusion injury.

Extensive studies have been performed over the past $30+$ years to develop strategies to limit ischaemia and reperfusion (IR) injury [68, 69]. Although many have been identified that are cardioprotective in animal models, none have yet been translated effectively to patients. One of the first cardioprotective drug cocktails investigated, glucoseinsulin-potassium therapy, was found to protect in animals studies, but in clinical trials of totalling over 27,000 patients with acute coronary syndrome, no convincing benefit was seen [92] (reviewed in [100]). A phase III trial of cariporide, an inhibitor of the sodium hydrogen exchanger isoform-1 (NHE-1), in patients undergoing coronary artery bypass graft surgery, found a highly significant reduction in myocardial injury, although this was unfortunately accompanied by a significant increase in cerebrovascular events and mortality [132]. More recently, remote ischaemic conditioning (RIC), which is clearly effective in animal models [22], had no benefit on either myocardial infarct size or clinical outcomes at 12 months in the multi-centre CONDI-2/ERIC-PPCI trial of 5401 STEMI patients treated with PPCI [70]. One class of agents that has shown some promise in clinical trials are the glucagon-like-peptide-1 analogues such as exenatide and liraglutide [26, 122, 222], although so far they have only been studied in small, proof-of-concept trials.

Possible reasons for the failures of translation described above have been extensively discussed $[68,69,76]$. One issue that has been widely discussed is the fact that most rodent studies of MI are performed in healthy, young animals, whereas the typical cardiac patient is elderly, and may exhibit complex multi-morbidity [19, 36, 176, 202]. Attempts have been made to overcome this issue by using models of hypertension, hyperlipidaemia, diabetes, age etc., and indeed, these have been seen to have an effect on the signalling pathways involved in cardioprotection $[6,43,119$, $120,162,218]$. This has led to the proposal that multitarget strategies will be required to effectively reduce IR injury in patients [32]. Clearly, however, the most prevalent morbidity in the STEMI patient population is coronary atherosclerosis. Angiographic studies find evidence of significant obstructive coronary artery disease in $\sim 95 \%$ of MI patients $[33,34,155]$. Surprisingly few IR studies have been performed in animal models of atherosclerosis, and the results of these are highly divergent, finding that atherosclerosis increases, decreases or has no effect on infarct size (Table 1). One explanation for this may be that most rodent models of atherosclerosis do not completely mimic the pathophysiology of the atherosclerotic coronary artery. For example, in mice, a major limitation is that atherosclerotic plaques tend to manifest most frequently in the aorta and proximal great vessels, and they are rarely, if ever, seen in the coronary vessels [206].

Mice are the most widely used species for reasons of cost, convenience, and their ability to be genetically manipulated. In this review, we examine the main mouse models of atherosclerosis currently available, their method of creation, pathology, coronary arterial function and response to cardiac IR. The aim is to identify which, if any, mouse model of atherosclerosis is suitable for investigating new cardioprotective drugs and strategies that will be clinically translatable to humans.

In humans, the left anterior descending (LAD) artery supplies a large territory of the ventricular myocardiumtherefore, LAD occlusion tends to lead to larger infarcts and worse prognoses [40, 97]. As the main cause of MI in patients is plaque rupture, animal models would ideally include this event. However, since the timing of plaque rupture, and the location and size of the ischaemic area that result are all unpredictable, this is not experimentally practical. In any case, in most rodent models of atherosclerosis, the plaques rarely rupture $[15,236]$. Therefore, in rodent IR studies of MI, the left coronary artery (equivalent to the LAD in humans [18]) is ligated at a specific location for 30-40 min, followed by reperfusion, which leads to infarction of $\sim 40-60 \%$ of the AAR [18]. This degree of injury provides sufficient potential to detect salvage of the remaining viable tissue by cardioprotective interventions. In some studies, a model of permanent coronary artery ligation (CAL) is used, although this does not reflect the clinical scenario in which the occluded vessel is opened to reperfuse the ischaemic area as soon as possible. It is also important to note that after a certain duration of ischaemia (45-90 min in rodents and pigs, depending on the extent of coronary collateral vessels), $90 \%$ of the AAR will be infarcted, and therefore, no significant reduction in acute infarct size is possible [14, 181]. Since only limited data is available, we will discuss both studies using either acute, reperfused (IR) or chronic ischaemic (CAL) models of MI.

\section{How does atherosclerosis develop in humans?}

Atherosclerosis is a progressive inflammatory disease characterised by the accumulation of oxidized lipids in the arterial wall leading to the development of atherosclerotic 


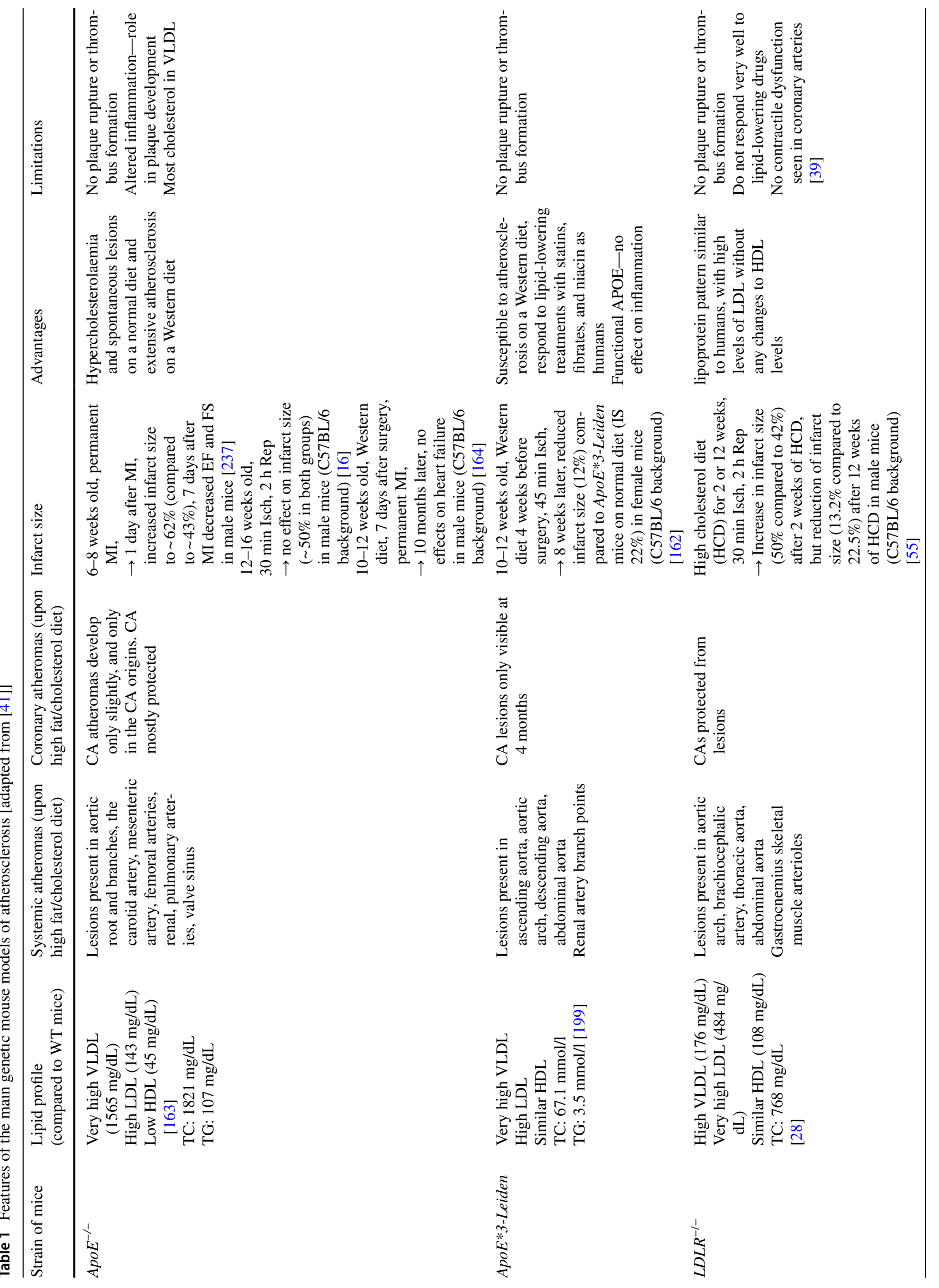




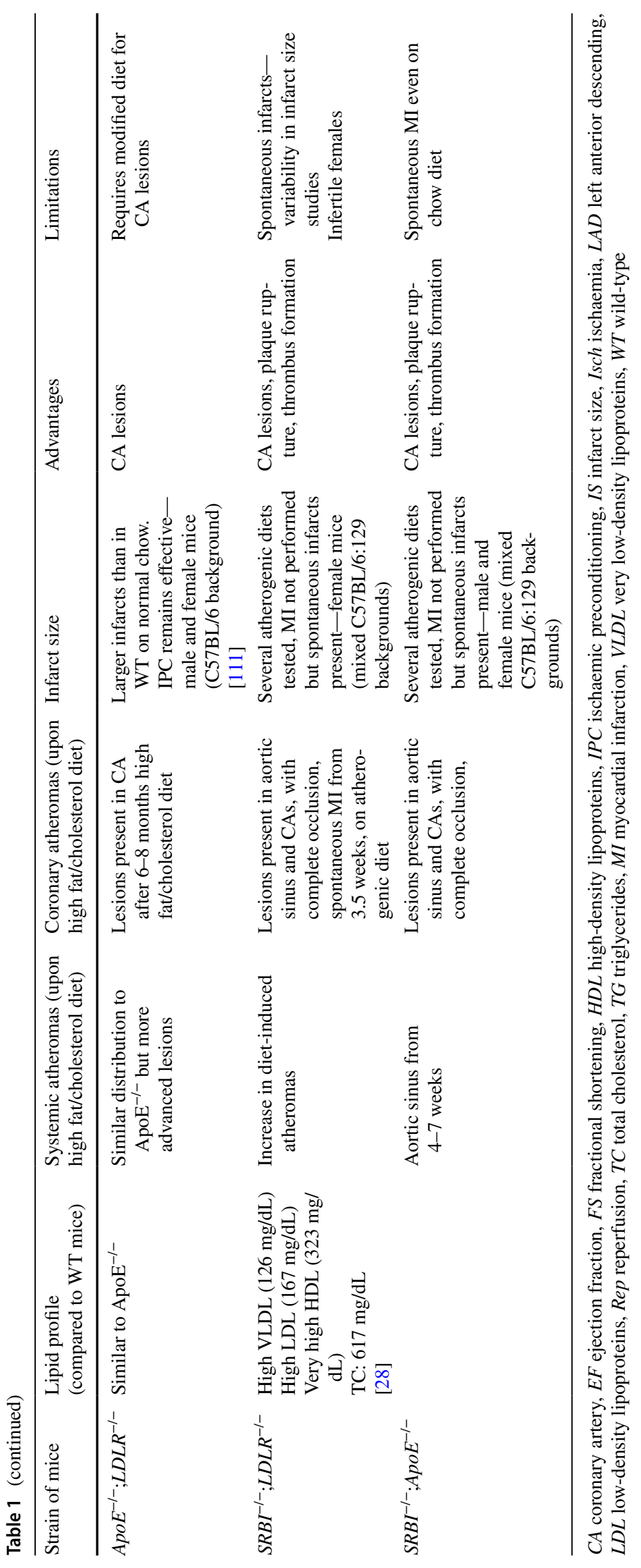


lesions (Fig. 1). These lesions gradually harden and cause narrowing of the arterial lumen. They can remain stable for many years, but can eventually become large enough to impede the flow of blood through the vessel lumen to cause ischaemia. The major consequences of acute or chronic obstruction are MI, stroke, or peripheral artery disease, depending on the affected artery. Atherosclerotic plaques leading to acute coronary events tend to occur in the left anterior descending coronary artery, right coronary artery and the left circumflex arteries, and cluster within the proximal third of the vessel $[54,216]$. Here, plaque rupture can initiate thrombosis formation, causing acute MI.

Several risk factors can modify the extent and rate of atherosclerosis development, including hyperlipidaemia, smoking, sex, diabetes and hypertension [230]. A key player in the development of atherosclerosis is an increase in plasma levels of cholesterol-rich lipoproteins such as low-density lipoprotein (LDL) [118, 146, 189]. Many studies have shown that oxidised LDL particles promote the progression of atherosclerosis [134, 142]. Endothelial dysfunction in the artery causes modification of the APOB-containing LDL and triggers the infiltration of monocytes into the artery wall. Due to the impaired function of the endothelium, LDL particles can deposit in the arterial wall and are retained by the extracellular matrix $[17,116]$. LDL particles accumulate and bind to intimal proteoglycans, forming aggregates. These can then enter smooth muscle cells via LDL receptors [121]. Activation of the vascular endothelial cells also leads to the expression of cell adhesion molecules, such as VCAM-1 and ICAM-1, which facilitate the binding and adherence of immune cells such as monocytes to the arterial wall [82, 147]. These monocytes differentiate into macrophages. As
1. Healthy vessel
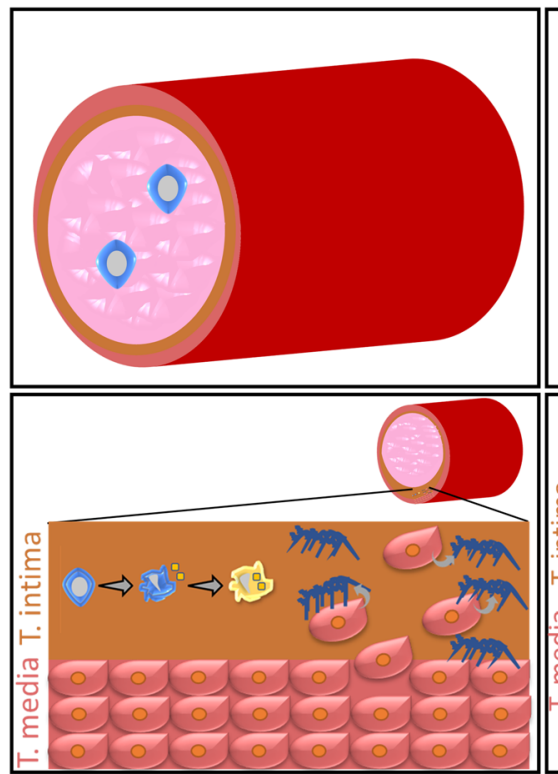

4. Fibrous plaque
2. Initial lesion

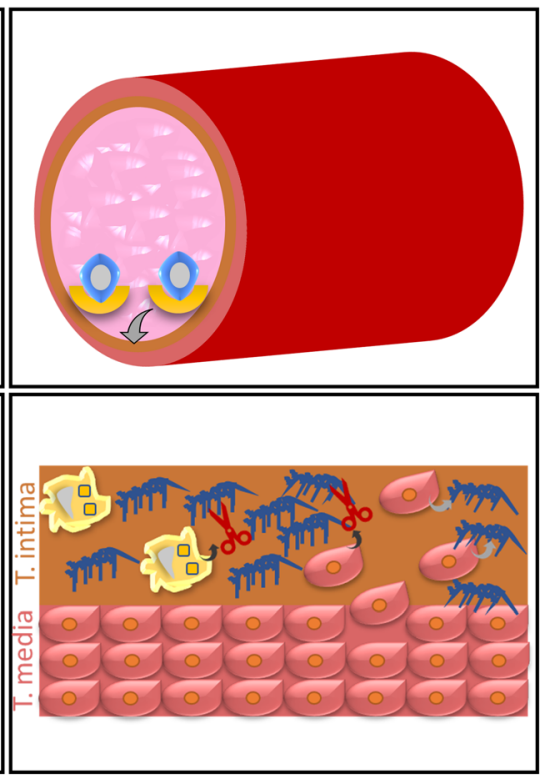

5. Advanced plaque
3. Fatty streak

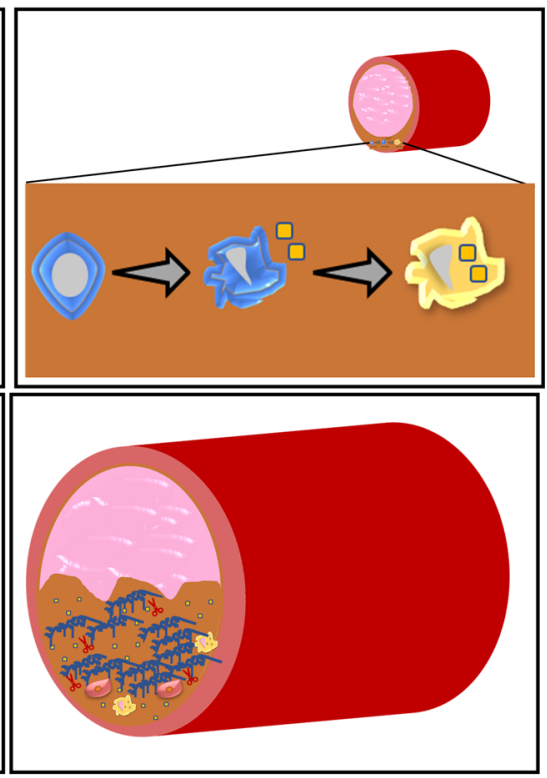

6. Vulnerable plaque and thrombus

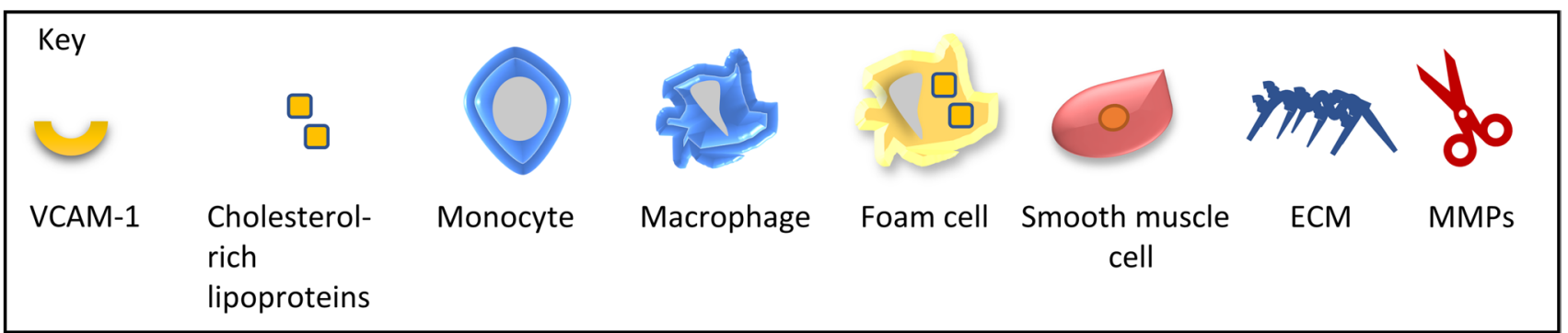

Fig. 1 Process of atherosclerotic lesion development. 1 Monocytes circulate in the circulation in a healthy vessel. 2 Endothelial dysfunction leads to the expression of cell adhesion molecules such as VCAM-1 by activated endothelial cells. These cell adhesion molecules allow monocytes to adhere to the wall and infiltrate to the tunica intima. 3 Monocytes differentiate into macrophages and engulf cholesterol-rich lipoproteins, becoming foam cells. 4 Smooth muscle cells (SMCs) infiltrate and stimulate the production of extracellular matrix components. 5 Foam cells and smooth muscle cells release matrix degrading matrix metalloproteinases (MMPs). 6 Degradation of the extracellular matrix (ECM) by MMPs increases plaque vulnerability to rupture and thrombus formation 
cholesterol levels rise, the expression of the high-affinity LDL receptor drops but expression of the high-affinity scavenger receptors for LDL particles does not. These scavenger receptors allow the loading of macrophages with the excess cholesterol, forming foam cells and triggering inflammation $[13,49,50,136]$. Importantly, in terms of investigating cardioprotective strategies, myocardial-resident macrophages have been associated with both injury [229] and repair [35] in response to MI. Foam cells can induce further inflammation by releasing cytokines such as interleukin-1 $\beta$ (IL-1 $\beta$ ) and tumour necrosis factor- $\alpha(\mathrm{TNF}-\alpha)[117,131]$. Activated smooth muscle cells release extracellular matrix proteins such as collagen and elastin, which promote the formation of the fibrous cap [144]. Foam cells and extracellular lipid particles build up under the fibrous cap generating the necrotic core. As the atherosclerotic plaque progresses, the fibrous cap becomes more prone to rupture and releases its contents into the blood. This triggers thrombus formation and can lead to MI or stroke [67].

High-density lipoprotein (HDL), APOE and APOA-I counteract lesion development by promoting cholesterol efflux from peripheral tissues and preventing inflammation $[65,165,213]$. Nonetheless, inflammatory cytokines facilitate the infiltration and proliferation of smooth muscle cells into the lesion, which produce the extracellular matrix (ECM) forming a fibrous layer. Foam cells, and to a lesser extent smooth muscle cells and endothelial cells, release matrix-degrading metalloproteinases (MMPs). These can degrade all components of the ECM [48, 72, 224]. The degradation of the ECM increases the vulnerability of plaques to rupture. Plaque rupture leads to thrombus formation with aggregated platelets, blood coagulation and blockage of blood flow. The consequence of this occurring in a coronary artery is an acute MI.

Atherosclerosis is a chronic inflammatory disease, accompanied by innate and adaptive immune responses [221]. LDL and oxidised LDL act as self-antigens, stimulating $\mathrm{CD} 4^{+} \mathrm{T}$ cells, and driving an autoimmune response in atherosclerotic lesions fuelling plaque inflammation $[98,191] . \mathrm{CD}^{+} \mathrm{T}$ cells can differentiate into T-helper cells that induce B cells to produce high-affinity IgG antibodies against LDL, oxidised LDL and APOB. These antibodies can either be atheroprotective or contribute to the progression of disease [221]. In patients with atherosclerosis, APOB-specific regulatory $\mathrm{T}$ cells appear to be atheroprotective by inhibiting atherogenic T-cell subsets and suppressing inflammation [5]. Nonetheless, as atheromas develop, this initial protective immune response promotes endothelial dysfunction, formation of foam cells and cell death via secretion of interferon- $\gamma$ (IFN$\gamma$ ) [5]. Therefore, despite initial atheroprotective features, with its potential to be both pro- and anti-inflammatory, the adaptive immune system can become pathogenic. The balance between a pro-inflammatory or anti-inflammatory response is partially controlled by genetics, which is relevant when considering the mouse models described below, which typically have low genetic diversity. Furthermore, differences in the immune system of mice and humans renders the direction and amplitude of autoimmunity in humans difficult to predict from mouse models [221].

The "response-to-injury" hypothesis of atherogenesis as defined by Ross proposes that "injury" to the endothelium is the initiating event in atherogenesis [175]. Furthermore, since the CANTOS trial, the involvement of inflammation in atherosclerosis is now firmly established [169]. Each of these aspects (lipids, endothelial function, chronic inflammation) could potentially influence MI. Therefore, the ideal experimental model of atherosclerosis for use in investigating cardioprotective strategies would entail all three aspects.

\section{Coronary endothelial dysfunction precedes atherosclerosis}

Impaired endothelial function and arterial vasomotion can be observed prior to the arterial stiffening and remodelling that occurs as atherosclerosis proceeds. For example, epicardial and microvascular coronary endothelial dysfunction independently predict acute cardiovascular events in patients with coronary artery disease (CAD) [66]. Whereas acetylcholine causes vasodilation of healthy arteries, it induces paradoxical vasoconstriction in atherosclerotic coronary arteries with advanced stenosis and even in many arteries with minimal disease [123]. In contrast, smooth muscle function is less affected by atherosclerosis [123].

Nitric oxide (NO) is a key mediator of vascular homeostasis, modulating smooth muscle proliferation, inflammation, platelet activation, and vascular tone, each of which can impact the development of atherosclerosis. A major source of NO is nitric oxide synthase (NOS) in the endothelium. In healthy vasculature, endothelial NO suppresses the development of atherosclerosis by inhibiting platelet aggregation, inhibiting LDL oxidation, preventing infiltration of leukocytes into the vascular wall and inhibiting smooth muscle cell proliferation and constriction [46, 113, 114]. Importantly, however, endothelial NOS is impaired by atherosclerosis, and it can even produce damaging superoxide instead. Therefore, as with the adaptive immune system, an increase in $\mathrm{NO}$ can be either protective or deleterious in the setting of atherosclerosis, depending on its levels and duration $[60,195]$.

In a substantial number of STEMI patients in whom epicardial coronary artery reperfusion is achieved, reperfusion at the myocardial tissue level remains incomplete [145]. This is referred to as "no reflow" and is due to microvascular obstruction (MVO). As a consequence, despite apparent successful epicardial recanalization, the myocardium remains ischaemic, and will become infarcted [14]. Although MVO 
is independently associated with adverse ventricular remodelling and patient prognosis, MVO is not currently routinely measured or treated in patients. Contributing factors to MVO include coronary microvascular dysfunction and vasoconstriction, and physical obstruction of the microvessels by damaged endothelial cells or micro-embolization of atherosclerotic debris [75]. This provides a strong rationale for the use of animal models with coronary artery atherosclerosis, as this may affect the outcome of IR and cardioprotection studies.

Atherosclerosis sufficient to cause stenosis and ischaemia gradually affects the entire structure of the coronary tree by stimulating the development of coronary collateral vessels, such that they are detected in up to $\sim 70 \%$ of patients with acute MI [183, 215]. This is important because residual blood flow carried by collaterals at the time of acute MI can limit infarct size.

In mouse studies, the aorta is commonly used to assess vascular function because its size makes it easier to study than other arteries [4, 9, 177]. This is not ideal for the study of atherosclerosis, however, since its first symptoms are not usually caused by plaques in the aorta, but rather the obstruction of flow through conduit arteries supplying major organs such as the heart or brain. Furthermore, both endothelium-dependent and -independent vasodilation differ significantly in magnitude between the aorta and other arterial segments from carotid, femoral, mesenteric, renal and coronary arteries [99]. The aorta is, therefore, not a good surrogate to study vascular function in other arteries.

\section{Mouse models of atherosclerosis}

Most animal models of atherosclerosis are based either on feeding with a diet enriched in fat and cholesterol, or the introduction of genetic modifications known to alter cholesterol metabolism.

\section{Diet-induced models of atherosclerosis}

The first animal model of atherosclerosis was developed in rabbits by feeding them a diet enriched in animal proteins (milk, meat and eggs), which resulted in lesions with a build-up of foam cells in the aorta [81]. Since that time, diets containing differing concentrations of fat, cholesterol and cholate have been widely used to induce atherosclerosis in animal models [53, 225]. Cholate, a bile acid that facilitates the digestion and absorption of lipids in the small intestine, has been used extensively to induce atherosclerosis, but is not ideal as it may cause nonspecific toxicity $[47,108,109$, $210,211]$.
Vesselinovitch et al. developed the first atherosclerotic mouse model using a diet consisting of 30\% fat, 5\% cholesterol, and $2 \%$ cholic acid; however, this severe diet also resulted in weight loss and respiratory infections [211]. Paigen et al. found that when they reduced the fat content of the diet to $15 \%, \mathrm{C} 57 \mathrm{BL} / 6$ mice developed atherosclerosis more slowly, with lesions with fatty deposits and foam cells in the aorta appearing by 14 weeks [153]. Of note, the lesions were largely confined to the aortic root and did not develop further than a fatty streak [153]. To achieve plaques resembling human intermediate lesions and beyond, other models are required.

\section{Infarct size}

Two weeks of high fat and cholesterol diet prior to surgery had no impact on infarct size in C57BL/6 mice subject to 30 min LAD ligation and $2 \mathrm{~h}$ reperfusion [55]. Surprisingly, however, after 12 weeks of high fat and cholesterol diet, infarct size after IR was significantly smaller than those on a normal diet [55]. In a separate study, a C57BL/6 J sub strain called C57BL/6JBomTac were fed an obesogenic diet containing $60 \%$ fat for 33 weeks and their hearts were isolated and subject to $30 \mathrm{~min}$ of global ischaemia and $60 \mathrm{~min}$ of reperfusion in a Langendorff model [37]. Infarct size was reduced in mice that were on the obesogenic diet, compared to those on a normal diet [37]. This could be due to an increase of the signalling substance sphingosine-1-phosphate (S1P) in obesogenic animals [74, 193]. S1P mediates endothelial barrier tightening $[29,180,223]$ and may diminish the endothelial leakage with interstitial oedema formation, which is a major component of IR injury [74, 193].

Even though wild-type mice exhibit signs of dyslipidaemia upon a Western diet, their complicated phenotype must be considered when being used as a model of atherosclerosis. Besides hyperlipidaemia, these mice exhibit hyperglycaemia, corresponding to a diabetes mellitus type II phenotype. Therefore, their cardiac function and response to I/R and cardioprotective strategies can be potentially affected by the multi-faceted metabolic syndrome they exhibit [6].

\section{Limitations of the model}

These early models helped to establish the role of cholesterol in atherogenesis, but are typically obesogenic, which is a potential confounding factor. Furthermore, the non-physiological nature and potential toxicity of cholate-containing diets suggest that atherogenesis in these mice may not accurately reflect the human disease [210]. 


\section{Transgenic mouse models of atherosclerosis}

A number of genes with a critical role in the development and progression of atherosclerosis have been identified, and these have been exploited for the development of transgenic mouse models with enhanced atherogenesis. However, each model has its advantages and limitations which will be discussed.

\section{ApoE knockout mice}

\section{Model}

Apolipoprotein E (APOE) is involved in lipoprotein metabolism and lipoprotein-mediated lipid transport [7, 105]. It associates with plasma lipoproteins and plays a major role in their production, conversion and clearance from the blood $[90,105,209]$. The mouse APOE protein is $~ 70 \%$ homologous to the human protein $[158,161]$. APOE is carried by chylomicrons and VLDL in plasma and acts as a ligand to mediate the uptake of these remnants by LDL receptor on the surface of hepatic cells, which remove them from the circulation [127, 205]. Knockout mice lacking APOE were developed in 1992, bringing the first mouse genetic model of atherosclerosis into existence [158, 161]. ApoE knockout mice $\left(A p o E^{-l-}\right)$ mice display delayed lipoprotein clearance and develop dyslipoproteinemia, hypercholesterolemia and atherosclerotic lesions even when fed normal chow [214].

\section{Lipid profile and cardiac and peripheral atheromas}

$A p o E^{-/-}$mice on a normal chow diet have significantly increased levels of total plasma cholesterol in comparison to wild-type mice [140]. In humans, plasma cholesterol levels less than $200 \mathrm{mg} / \mathrm{dL}$ are considered healthy, whereas $>240 \mathrm{mg} / \mathrm{dL}$ is considered high. In wild-type mice on a chow diet total plasma cholesterol levels are only $75-110 \mathrm{mg} / \mathrm{dL}$, but in $A p o E^{-1-}$ mice they are dramatically increased to $400-600 \mathrm{mg} / \mathrm{dL}$ [140]. Even if this level is much higher than in patients, the fact that hypercholesterolemia and lesions develop spontaneously on a normal chow diet makes $A p o E^{-l-}$ mice favourable to diet-induced models. In the plasma, APOE is associated with chylomicron remnants and VLDL. After binding to the LDL receptor with high affinity, APOE plays a key role in the clearance of VLDL and remnant proteins [166]. In comparison to wild-type mice, loss of APOE decreases levels of HDL and increases VLDL and LDL cholesterol levels [77, 87]. On a normal chow diet, lesions appear by 6 weeks of age. The presence of foam cells and smooth muscle cells in the lesion is observed at $8-10$ weeks and fibrous plaques appear at 15 weeks. A
Western-type diet can accelerate the growth and extent of the lesions depending on the requirements of the study. In $A p o E^{-/-}$mice, the pattern of lesion distribution in the heart is very different from that of humans. The lesions in these mice tend to form throughout the vasculature including in the aortic root and branches, the carotid artery, mesenteric artery, renal and pulmonary arteries as well as the valve sinus $[27,140]$. The major lesions are located in the valve sinus, including the origins of the coronary arteries, but the lesions extend only a short distance onto the arterial trunks $[80,148]$. Consequently, unlike in humans, the first segment and first branch of all the major coronary arteries are protected from disease $[80,148]$. Despite the lack of robust atherosclerosis in coronary arteries of these mice, the lesions are a good model for the developmental process of the human disease in non-cardiac arteries. Interestingly, it has recently been shown transverse aortic constriction (TAC) performed in in $A p o E^{-/-}$mice leads to coronary plaque formation, progression, and myocardial events [129]. Furthermore, in several of the TAC-induced $A p o E^{-/-}$mice, evidence of myocardial infarction caused by embolism was obtained [129], which suggests the model could be used for studying no reflow caused by microemboli.

In regards to peripheral atheromas in $A p o E^{-/-}$mice, studies of the skeletal muscle of these mice demonstrate decreased capillary density from 12 weeks. Levels of nitric oxide, one of the key players in skeletal muscle function and metabolism [168], decline from the age of 20 weeks [187, 188]. Interestingly, isolated, Langendorff-perfused $A p o E^{-/-}$hearts displayed reduced nitric oxide-dependent vasodilation at the level of coronary resistance vessels [56]. In addition to extensive plaque formation in the aorta, plaques were observed in the femoral arteries of $A p o E^{-/-}$mice at the age of 65 weeks [11]. In $A p o E^{-/-}$mice, an increase in inflammation and a higher level of hydrogen peroxide in skeletal muscle were observed when compared with wild-type mice suggesting a protective role for APOE in peripheral arteries [159].

\section{Infarct size}

In 12-16 week old $A p o E^{-/-}$mice, there was no difference between the area at risk or infarct sizes following $30 \mathrm{~min}$ regional ischaemia of the myocardium followed by $2 \mathrm{~h}$ reperfusion, compared to wild-type mice [16] (Table 1). The impact of APOE deficiency on MI-induced heart failure was investigated by performing chronic LAD ligation in 6-8 week old $A p o E^{-/-}$mice. One day following permanent $\mathrm{CAL}$, infarct size and myocardial injury were significantly greater in $A p o E^{-/-}$mice compared to wild type, as assessed by TTC staining, cTnI and CK-MB [237]. In contrast, in a separate study in which mice were fed a Western diet from the $7^{\text {th }}$ day following permanent 
CAL, no effects of APOE deficiency were observed on infarct size, survival or the development of heart failure over the following 10 months [164]. Infarct size was also similar between wild type and $A p o E^{-/-}$mice when using an IR model, which consisted of $30 \mathrm{~min}$ ischaemia and $2 \mathrm{~h}$ reperfusion [38]. Only one study has addressed whether cardioprotection remains effective in $A p o E^{-/-}$. This showed that saffron aqueous extract reduces myocardial infarct size in both $A p o E^{-/-}$and wild-type mice to a similar extent [38]. Though $A p o E^{-/-}$mice have been extensively studied, it is surprising to find only one study on cardioprotective strategies in this strain. Further research of cardioprotection in $A p o E^{-/-}$mice would be informative and aid the translation of therapeutic strategies into patients with atherosclerosis.

\section{Limitations of the model}

There are several caveats to using this model for studies of MI. Thrombotic occlusion rarely occurs in the coronary arteries of $A p o E^{-/-}$mice, unlike in humans, making it more difficult to extrapolate findings into the clinic, as the effect of atherosclerosis on MI could be different to that which occurs in humans. The low prevalence of plaque rupture in mice could potentially be due to the small diameter and the lower surface tension of the mouse vessel in comparison to humans [88]. Nonetheless, the plaques in the brachiocephalic artery of older (42-60 weeks) $A p o E^{-1-}$ mice are more similar to human plaques, involving intra plaque haemorrhage, an acellular necrotic core and erosion of the necrotic mass into the lumen [173]. In a study of $A p o E^{-/-}$mice after 8 weeks of fat feeding, plaque rupture was observed in the brachiocephalic arteries at high frequency [93]. Plaque rupture has been extensively studied in $A p o E^{-/-}$mice and it appears that brachiocephalic arteries and the aorta are the main arteries where plaque rupture occurs in this model [24, 93, 219]. Moreover, APOE has an impact on inflammation, oxidation, reverse cholesterol transport by macrophages and proliferation and migration of smooth muscle cells from tunica media in the vessel wall into the tunica intima, which could play a role in plaque development in $A p o E^{-/-}$mice regardless of changes in the lipid profile [52]. Following MI, Ly-6 $\mathrm{C}^{\text {hi }}$ monocytes digest damaged tissue in the first 4 days and $\mathrm{Ly}-6 \mathrm{C}^{\mathrm{lo}}$ monocytes facilitate angiogenesis and repair of the tissue from days 5-10 [139]. Inflammatory gene expression and protease levels associated with the activity of Ly-6C $\mathrm{C}^{\text {hi }}$ monocytes, were more pronounced in $A p o E^{-/-}$mice 5 days after MI [154]. APOE is a multifunctional protein with roles in inflammation, oxidation, smooth muscle proliferation and migration as well as reverse cholesterol transport by macrophages. Thus, changes in these functions may affect the development of atheromas in $\mathrm{ApoE}^{-/-}$mice, independent of their changes in lipoprotein profile [52]. Another limitation to be considered with $A p o E^{-/-}$mice is the high levels of VLDL particles, which is not typical in human atherosclerosis [163].

\section{ApoE*3-Leiden mice}

\section{Model}

In an uncommon disorder of lipoprotein metabolism called familial dysbetalipoproteinemia (FD), the $A p o E$ gene is mutated, which results in reduced binding to receptors and decreased clearance of the remnants. The accumulation of these particles results in hypercholesterolemia and hypertriglyceridemia, predisposing FD patients to coronary artery disease and peripheral artery disease. ApoE*3-Leiden, a mouse model of FD, contains the human APOE3Leiden and APOC1 genes [199]. APOC1 inhibits lipoprotein lipase (LPL) which is involved in the lipolysis of triglyceride-rich lipoproteins [107]. As in the human disease, the mutation in the $A p o E$ gene results in a dysfunctional protein with reduced binding to its receptors impairing the clearance of chylomicron remnants and VLDL [128, 220]. Consequently, these mice are susceptible to atherosclerosis when fed a high-fat diet. In contrast to other mouse models of atherosclerosis, they respond to lipid-lowering treatments such as statins, fibrates, and niacin in a similar way to humans $[8,102,198,201]$, which has made them a useful experimental model for drug development.

\section{Lipid profile and cardiac and peripheral atheromas}

On several diets tested, ApoE*3-Leiden mice developed enhanced aortic atherosclerosis compared to wild-type mice [63]. Total plasma cholesterol levels were significantly higher in ApoE*3-Leiden mice on both normal chow and high-fat diet [63]. The lipoprotein pattern on a high-fat diet was characterised by increased levels of VLDL and LDL and decreased levels of HDL (Fig. 2) [199]. Early lesions in ApoE*3-Leiden mice included those on aortic valves and the free aortic wall, which were superficial and contained one or two layers of lipid-loaded foam cells. Some of these lesions developed into more extensive plaques covering the entire arterial wall, and were rich in foam cells. With a more severe diet such as high fat and cholate for 3 months, more complex lesions developed, containing a lipid-laden core loaded with foam cells with calcification in certain sections [111]. 


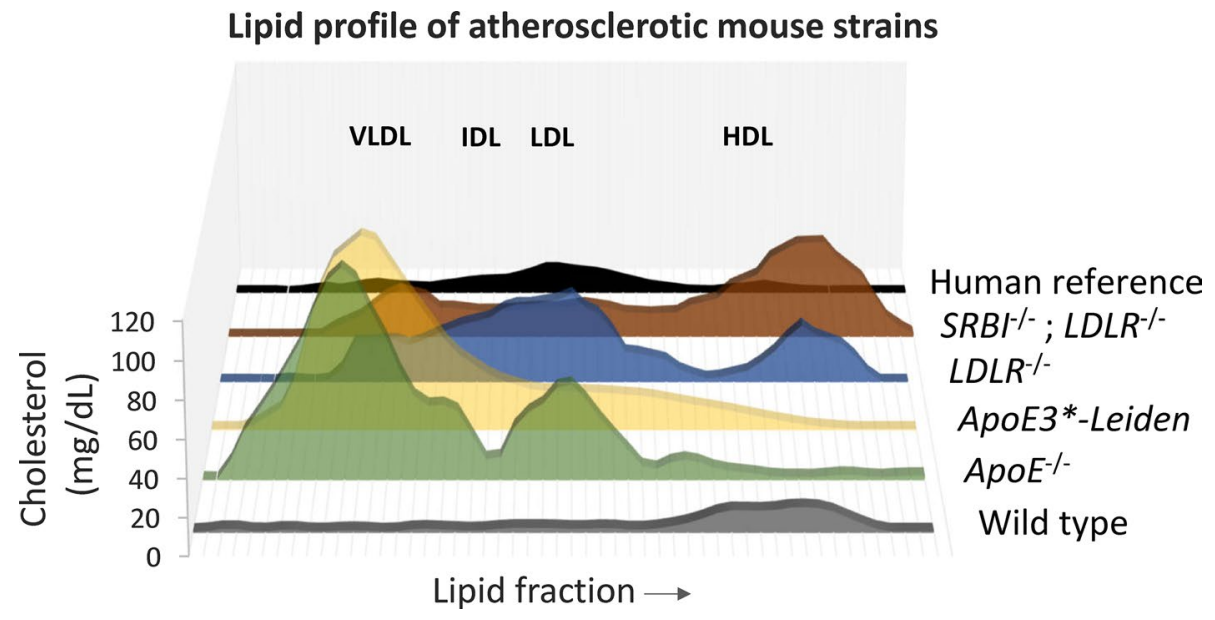

Fig. 2 Lipid profile of different knockout mouse models of atherosclerosis. Unlike humans, wild-type mice carry cholesterol primarily in HDL particles. In comparison to human, $A p o E^{-/-}$and $A p o E 3 *_{-}$ Leiden mice have very high levels of VLDL cholesterol, higher levels of LDL cholesterol and similar levels of HDL cholesterol. $L D L R^{-/-}$

Lesions were present in the ascending aorta, aortic arch, and descending aorta, whereas wild-type mice showed no lesions when fed the same diet [63]. However, none of the animals had lesions in the proximal coronary arteries [63]. In another study in which $A p o E^{*} 3$-Leiden mice were fed a special high-fat and cholesterol diet (15\% cacao butter, $0.5 \%$ cholate, $1 \%$ cholesterol, $40.5 \%$ sucrose, $10 \%$ corn starch, $1 \%$ corn oil, and $4.7 \%$ cellulose), extensive atherosclerosis was observed [124]. After 4 months, advanced lesions were present in the aortic root, the aortic arch and its main branch points. Plaques were also present in the abdominal aorta and renal artery branch points [124]. Early lesions (fatty streaks) were observed in the proximal coronary arteries, and these had become advanced by 6 months [124]. After 12 months, calcifications were seen in the coronary arteries of some mice.

The major differences between humans and ApoE*3Leiden mice are the lack of plaque rupture, thrombus formation and haemorrhage in these mice [174]. The possible reasons for this could be due to the morphologically intact endothelial layer, which prevents rupture, and the low level of apoptosis in the fibrous cap.

\section{Infarct size}

There are few infarct studies in ApoE*3-Leiden mice to date, even though these mice appear to be a suitable animal model of atherosclerosis [199]. Nonetheless, one study has investigated the effect of 4 week diet-induced hypercholesterolemia on left ventricle (LV) remodelling following IR in these mice in comparison to normocholesterolemic ApoE*3-Leiden mice. Surprisingly, 8 weeks following IR, a significant mice have higher levels of all cholesterol-loaded lipoproteins and $S R B I^{-/-} ; L D L R^{-/-}$mice have higher levels of VLDL cholesterol, similar levels of LDL cholesterol and much higher levels of HDL cholesterol than humans [adapted from [28, 83, 163, 199]]

reduction in infarct size and an increase in wall thickness were observed in hypercholesterolemic mice, with less accumulation of infiltrated inflammatory cells [162]. Paradoxically, LV contractile function was significantly impaired in hypercholesterolemic ApoE*3-Leiden mice, reflected by a reduction in LV ESP, dP/dtMAX, and dP/dtMIN, though no differences of LV dimensions were observed [162].

\section{Limitations of the model}

One limitation of the ApoE*3-Leiden model is similar to the other mouse models of atherosclerosis in that thrombosis does not occur. Therefore, it is difficult to relate the data obtained from this strain to the clinic. In addition, lesions are not observed in the coronary arteries [63], or are only observed after a relatively long time of 6 months of high fat and cholesterol diet [124].

\section{LDLR knockout mice}

\section{Model}

The LDL receptor (LDLR) is a glycoprotein expressed on the surface of hepatocytes, which plays a key role in the endocytosis and removal of circulating LDL cholesterol. Besides the widely used $A p o E^{-/-}$mice, $L D L R^{-/-}$mice are one of the most popular choices amongst mouse models of atherosclerosis. Mutations in the $L D L R$ gene in humans cause familial hypercholesterolemia, with elevated plasma LDL cholesterol levels and deposition of cholesterol in 
vessels leading to the formation of atherosclerotic plaques $[23,110]$. Plasma cholesterol is moderately elevated in $L D L R^{-/-}$mice fed normal chow and they develop atherosclerosis gradually, although this can be accelerated on a high-fat diet $[101,137,182]$. The lipoprotein profile in the $L D L R^{-/-}$mice on chow diet is similar to humans, with high levels of LDL (Fig. 2) [84].

\section{Lipid profile and cardiac and peripheral atheromas}

The types and locations of lesions in $L D L R^{-1-}$ mice are similar to $A p o E^{-/-}$mice, and build up gradually with the earliest lesions seen in the proximal aorta. In general, the $L D L R^{-/-}$model is a milder model of atherosclerosis than the $A p o E^{-/-}$mice mainly due to the lower hyperlipidaemia observed [21, 184]. $L D L R^{-/-}$mice develop mild or no lesions when on a normal chow diet. Nonetheless, on a Paigen diet, the development of atherosclerosis is accelerated with significant increases in cholesterol levels and size of atherosclerotic plaques [85]. High-fat diet induced the development of atherosclerotic plaques with fatty streaks and accumulation of foam cells in the early lesions in the aortic root after 5 weeks [235]. Early lesions were also observed in the aortic arch and brachiocephalic artery and increased in size until they occupied most of the surface [125]. After one month on a high-fat diet, the tunica media had thickened significantly along with the appearance of lipid-laden macrophages. After 9 months, advanced lesions caused narrowing of the brachiocephalic artery. Surprisingly, lesions in the thoracic aorta were only visible after 6 months of high-fat diet, and abdominal aorta lesions were only detected after 9 months, although they increased significantly after this time point [125]. These changes in the rate of development for lesions in different regions, results in variable sensitivity to treatments that alter atherosclerosis. In terms of its effect on the peripheral circulation, LDLR loss leads to a decrease in capillary density in the gastrocnemius muscle by the age of 22 weeks, and the ratio of wall to lumen in skeletal muscle arterioles is elevated [187]. Importantly, no evidence of endothelial dysfunction was seen in functional studies of mesenteric artery, coronary artery or aorta of $\mathrm{LDLR}^{-/-}$fed either normal chow or Western diet for 8 weeks [39].

$L D L R^{-/-}$mice have been crossed with $A p o E^{-/-}$mice to generate $A p o E^{-/-} ; L D L R^{-/-}$double knockout mice. These have a similar lipid profile to $A p o E^{-/-}$mice, with a marked increase in VLDL and chylomicron remnants [86]. After 6-8 months of a high-fat and cholesterol diet, the $A p o E^{-/}$; $L D L R^{-/-}$develop extensive atherosclerotic lesions throughout the coronary tree [112]. Interestingly, the vasoconstrictor response to endothelin-1 (ET-1) was enhanced in thoracic aortic rings of $A p o E^{-/-} ; L D L R^{-/-}$mice in comparison to wild-type mice [91]. However, endothelial-dependent acetylcholine-induced relaxation was significantly impaired
[91]. The combined administration of L-arginine and $\mathrm{BH}(4)$ reversed the endothelial dysfunction of the $A p o E^{-/-}$; $L D L R^{-/-}$mice [91].

\section{Infarct size}

Interestingly, after 30 min LAD ligation and reperfusion for $2 \mathrm{~h}$, infarct size in $L D L R^{-/-}$mice was roughly half that seen in wild type [55]. After feeding $L D L R^{-/-}$mice a high cholesterol diet for 12 weeks, infarct size following IR was further reduced to a significant degree, leading the authors to suggest that prolonged exposure to high levels of plasma cholesterol protects the myocardium from IR injury [55]. This is surprising since it contrasts with the majority of previous studies on hypercholesterolemia in other animal models $[58,150,212]$. However, the interpretation of this data is complicated since in the same study, a shorter, 2 week diet caused a dramatic doubling of infarct size following IR [55]. The authors suggested that this may be due in part to the extremely high levels $(>2000 \mathrm{mg} / \mathrm{dL})$ of cholesterol that are obtained in $L D L R^{-/-}$mice following the high-fat diet.

Hearts were isolated from $A p o E^{-/-} ; L D L R^{-/-}$mice on a high-fat and cholesterol diet, and Langendorff perfused. Following $40 \mathrm{~min}$ global ischaemia and $60 \mathrm{~min}$ reperfusion, $A p o E^{-1-} ; L D L R^{-/-}$hearts had larger infarcts, more troponin $\mathrm{T}$ release, and worse cardiac function than wild-type mice [112]. However, because the wild type mice were fed normal chow, the difference could be due either to hypercholesterolemia or atherosclerosis. Interestingly, ischaemic preconditioning (IPC) remained equally effective in both $\mathrm{ApoE}^{-/-}$; $L D L R^{-/-}$and wild type hearts [112].

\section{Limitations of the model}

Although it is a widely used model of atherosclerosis, $L D L R^{-1-}$ mice do not respond very well to lipid-lowering drugs used in patients, indicating possible pathophysiological differences compared to human disease [8, 231]. In addition, the discrepancy between humans and mouse models in general such as the lack of plaque rupture applies to the $L D L R^{-/-}$model. The combined $A p o E^{-/-} ; L D L R^{-/-}$model may be closer to the cardiac patients with coronary atheromas.

\section{SRBI knockout mice}

\section{Model}

Scavenger receptor class B, type I (SRBI) is an HDL receptor expressed on the surface of multiple cell types and mediates the selective uptake of plasma HDL cholesterol by the liver. Hence, it regulates HDL cholesterol levels, particle 
size, and metabolism of cholesterol by steroidogenic tissues [2, 104, 179]. HDL cholesterol levels inversely correlate with the risk of atherosclerosis, most probably due to the role SRBI plays in reverse cholesterol transport [59, 94, 192]. Excess cholesterol from peripheral tissues is removed and delivered to the liver from where it is either redistributed to tissues in which it is required, or removed by the gall bladder. HDL cholesterol content is pivotal to the development of atherosclerosis as it also plays a role in inflammation [12, 143].

The extracellular domain of human SRBI shares $80 \%$ sequence identity with the mouse protein. However, unlike mice, human hepatocytes express a second HDL-cholesterol receptor called cholesteryl ester transfer protein (CETP) [79, $178,208]$. Human SRBI has a similar function to the mouse protein and a similar pattern of expression [1, 106, 138]. In endothelial cells, SRBI is functionally involved in NO production resulting in the attenuation of monocyte adhesion [64]. In addition, HDL binding to SRBI on platelets inhibits aggregation and increases platelet survival [79, 178, 208]. One important point for studies involving $\mathrm{SRBI}^{-1-}$ mice is that deficiency of SRBI in female mice can cause infertility due to defects in oocyte development [133].

SRBI is a key regulator of HDL cholesterol levels and its overexpression leads to an increase in biliary cholesterol content in support of gene-targeting studies that suggest SRBI plays a key role in reverse cholesterol transport [170, 207, 217]. Moreover, SRBI binds LDL and VLDL to promote the efflux of un-esterified cholesterol from cells to HDL $[89,186]$. Inactivation of SRBI leads to decreased reverse cholesterol transport and increased plasma HDL cholesterol levels [170, 207]. SRBI deficiency does not affect hepatic cholesterol levels or key regulators of hepatic cholesterol homeostasis, such as HMG-CoA reductase, the lowdensity lipoprotein receptor, or cholesterol $7 \alpha$-hydroxylase (78).

\section{Lipid profile and cardiac and peripheral atheromas}

Several groups have used $S R B I^{-1-}$ mouse models to investigate the function of SRBI. On a chow diet, SRBI deficiency caused an increase in total serum cholesterol levels as a result of higher levels free cholesterol and an increase in the cholesterol carried in the HDL particles (Fig. 2) [203]. On a high-cholesterol Western diet for 20 weeks, $S R B I^{-1-}$ mice developed more atherosclerotic lesions at the aortic root in comparison to wild-type controls [203].

$S R B I^{-1-}$ mice have been crossed with other knockout strains to exacerbate the phenotype. Knockout of $S R B I$ in either $A p o E^{-/-}$mice or $L D L R^{-/-}$mice causes an increase in larger HDL particles, highlighting the role of SRBI in reverse cholesterol transport [28, 197, 203]. Absence of $S R B I$ in $L D L R^{-/-}$mice lead to a sixfold increase in diet-induced atherosclerosis [28]. No signs of coronary artery atheroma or ischaemic heart disease were identified when mice were fed a standard Western diet [115]. However, following 12 weeks on a modified Western diet containing higher $(0.5 \%)$ cholesterol, coronary artery atherosclerosis was observed, being most severe at the aortic sinus level. The mice also developed spontaneous cardiac ischaemia/ infarction systolic dysfunction and LV dilatation and died by 20 weeks [115].

A study on the effects of different high-fat diets with and without cholate and cholesterol has reported an increase in aortic sinus plaque formation and size as well as reduced survival in $S R B I^{-1-} ; L_{D L R^{-/-}}$mice in comparison to $L D L R^{-/-}$controls on all atherogenic diets tested [47]. Interestingly, all $S R B I^{-1-} ; L D L R^{-/-}$mice developed atherosclerosis in their coronary arteries when on atherogenic diets, though this burden did not correlate with plaque sizes in the aortic sinus. In contrast, mice fed normal chow developed little atherosclerosis in their coronary arteries by 22 weeks of age. Uniquely, the double knockout mice showed signs of thromboses, which stained for the platelet marker, CD41, in the coronary arteries [47].

In $\mathrm{SRBI}^{-/-} ; \mathrm{ApoE}^{-/-}$mice, substantial atherosclerotic plaques were observed in the aortic sinuses after 4-7-weekold on a chow diet, compared to absence of plaques in $A p o E^{-/-}$or $\mathrm{SRBI}^{-/-}$mice [197]. Coronary artery atherosclerosis with complete coronary artery occlusion was observed in $\mathrm{SRBI}^{-1-}$; $\mathrm{ApoE}^{-/-}$mice, and these mice spontaneously developed multiple MIs, cardiac dysfunction and death at 5-8 weeks when fed a chow diet [20]. Their coronary artery lesions were strikingly similar to human atherosclerotic plaques, with evidence of haemorrhage and clotting [20].

$S R B I^{-1-}$ crossed with mice harbouring the hypomorphic ApoE allele $A p o E^{\mathrm{R} 61 \mathrm{~h} / \mathrm{h}}$ display features of hyperlipidaemia upon a high-fat diet leading to coronary plaques, partially occlusive coronary stenoses, spontaneous MI and reduced survival, closely resembling human coronary artery disease [156, 233]. Most thrombi were in medium and large coronary arteries in the basal LV, which explains the septal location of the thrombotic coronary arteries, as septal arteries are direct proximal branches of the right or left coronary artery or the aortic sinus [44]. $S R B I^{-/-} ; A p o E^{\mathrm{R} 61 \mathrm{~h} / \mathrm{h}}$ mice display several of the previously identified features of human vulnerable plaques [226], such as the presence of cholesterol-rich plaques in larger vessels and proximal segments of the coronary tree, thrombi with a necrotic core, perivascular inflammation, MIs and spontaneous deaths [73]. Interestingly, coronary vasodilator response was assessed in these mice by coronary angiogram, and an impairment of NO-mediated dilation of conductance and microvessels was seen [156]. 


\section{Infarct size}

The involvement of SRBI in circulating cells in protection from atherosclerosis is demonstrated by studies in which restoration of $S R B I$ expression in bone marrow-derived cells in knockout models results in attenuation of coronary artery atherosclerosis, MI and cardiac enlargement in $\mathrm{SRBI}^{-1-}$; $A p o E^{\mathrm{R} 61 \mathrm{~h} / \mathrm{h}}$ mice [157]. All $S R B I^{-/-}$mice in this study exhibited coronary atherosclerosis, but increased heart weights and cardiac enlargement were observed only in a subset of mice. This suggests that the cardiac enlargement and fibrosis are the result of extensive coronary artery atherosclerosis in this model which appears to be reduced upon SRBI restoration, potentially through reduced levels of monocyte recruitment [157].

$S R B I^{-1-} ; L_{D L R^{-1-}}$ mice develop spontaneous infarcts as early as 3.5 weeks depending on the atherogenic diet [47]. Nonetheless, surgically-induced MIs have not yet been studied in any of the $\mathrm{SRBI}^{-/-}$mice and whether the presence of coronary artery atheromas have an impact on cardioprotection is yet to be investigated.

\section{Additional considerations}

In any mouse experiment, it is important to consider the genetic background of the strain of wild-type mice being used, as this can significantly affect the results obtained. A study of 16 different inbred mouse strains fed the Paigen diet for 14 weeks, found major differences in the extent of atherosclerotic lesions that formed in the aorta [152]. The commonly used strain C57BL/6 was one of the most susceptible, developing lesions by 7 weeks with large plaques in the aorta and coronary arteries, which continued to develop. Strain 129, a common background strain for transgenic studies, had smaller lesions, and other strains such as $\mathrm{C} 3 \mathrm{H}$, and CBA had no lesions at all after 14 weeks on the Paigen diet. Strains AKR and DBA/2 displayed fatty streaks or lesions by 7 weeks, but these did not grow in size [152]. Another point to consider is that the impact of co-morbidities such as atherosclerosis on endothelial function and myocardial infarction may be sex-specific $[160,196]$. It is, therefore, important to use both male and female mice in studies.

Transgenic models of atherosclerosis can also be highly dependent on the background strain. For example, deletion of ApoE causes an increase in HDL-cholesterol and triglycerides, which results in atherosclerotic lesions at the aortic arch, but these develop earlier in 129/SvEv mice than in C57BL/6 [126]. On the other hand, the atherosclerotic plaques in the aortic root develop faster in C57BL/6 mice [126], possibly reflecting anatomical differences between the two strains. In any case, these results highlight the contribution made by the genetics of the background strain to the development of atherosclerosis [126].

Several genes have been identified that can modify atherosclerosis development, and mutation of these can improve the modelling of aspects of atherosclerosis lacking from standard models. For example, heterozygous mutation of fibrillin-1 (Fbnl) in ApoE ${ }^{-/-}$mice leads to fragmentation of the elastic fibres in the vessel wall, resulting in a mouse model more prone to the formation of vulnerable plaques and plaque rupture $[200,204]$. These mice also manifested leaky plaque neo-vessels and intra plaque haemorrhage, resulting in plaque rupture, myocardial infarction, stroke, and sudden death [200]. Therefore, this model could serve as a highly translational model of atherosclerosis and atheroma rupture, as observed in patients. Whether such a model would provide a practical advantage in experiments designed to investigate cardioprotection, where the duration and extent of ischaemic injury is typically carefully controlled and reproducible, remains to be established.

A possible limitation of genetic models is that the majority result in complete absence of the protein throughout the life of the mice, from embryogenesis to adulthood. Viralmediated models have the advantage of allowing the induction of atherosclerosis in adults, more closely reflecting the human situation. For example, proprotein convertase subtilisin/kexin type 9 (PCSK9) is a serine protease with a key role in the degradation of LDLR in the liver [130, 232]. In humans, mutations in the PCSK 9 gene have been associated with hypercholesterolemia and CVD [141]. Adenoviral overexpression of PCSK9 in mice decreases LDLR levels, leading to increased plasma LDL levels [130]. Mice expressing a gain-of-function mutant of PCSK9 delivered by adeno-associated virus (AAV) and fed a Western diet, develop sustained hyperlipidaemia with an increase in LDL and VLDL levels [172]. Atherosclerotic lesions with vascular calcification were observed in the aortas within 15-20 weeks, similar to plaques in $L D L R^{-/-}$mice [57]. However, the phenotype, like in $L D L R$-/- mice, is a consequence of loss of LDLR expression, and so the model is similarly limited by the absence of plaque development in coronary arteries. Furthermore, the response appears to be highly strain dependent, with the strongest effect in C57BL/6, and PCSK9 may also have additional effects independent of the LDLR that may affect studies [30].

A further consideration in the use of mouse models is the methods used for the identification of atherosclerotic lesions. Plaques are usually visualised by ex vivo staining with OilRed Sudan IV or Van-Gilson staining [135]. Nonetheless, the ability of these techniques to identify small/early atherosclerotic lesions is limited, and more advanced imaging modalities such as ultrasound, PET or microCT might be better suited to evaluating atheroma progression in carotid arteries, aorta and even coronary circulation in mouse hearts 
$[25,190]$. Therefore, the limitations in translational value of in vivo models could be overcome by using robust techniques for plaque identification and localisation.

\section{Other animal models}

Given that few mouse models of atherosclerosis develop coronary artery plaques, it is worth asking the question of whether mice are the most suitable model for IR studies, or if other animal models are preferable. Rats have similar advantages to mice in terms of maintenance and cost. Nevertheless, due to the lack of a gall bladder, absorption of cholesterol is low in rats, and their lipid profile also differs substantially from that of humans (Fig. 3). In addition, it is difficult to induce plaque formation in rats by high-fat diet alone and most research in atherosclerotic rats combines the use of drugs and artificially induced endothelial injury $[171,228]$. Genetic modification in rats became feasible only recently due to the optimisation of gene editing technologies [227, 234].

In contrast to rodent models, larger animals are more challenging to maintain, have higher associated costs, and take longer to develop atherosclerotic lesions. Nonetheless, rabbits have been a popular choice when it comes to models of atherosclerosis and have particular advantages. Their sensitivity to high-fat diets, high rate of cholesterol absorption, the ease of converting exogenous cholesterol into plasma lipids and low cholesterol clearance levels make rabbit an attractive model to study atherosclerosis. However, their herbivorous diet leads to major differences in lipid metabolism in comparison to humans and raises questions about the suitability. Plaques in rabbits have a typical lipid core covered by a fibrotic cap that can lead to MI, making them a relevant model of atherosclerosis [42]. Although anatomy

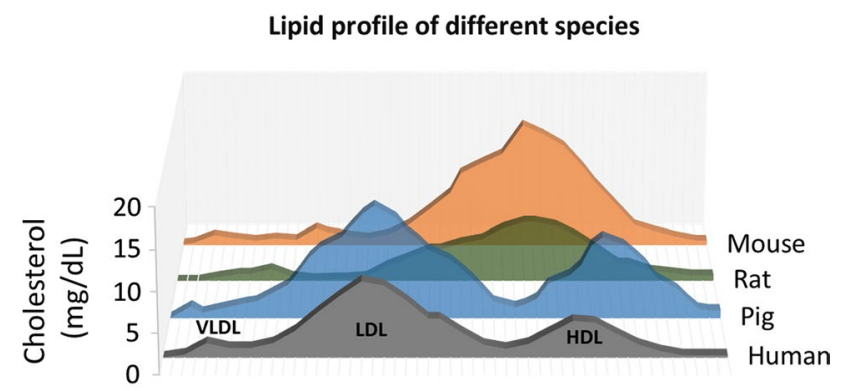

Lipid fraction $\rightarrow$

Fig. 3 Lipid profile comparison across species. In contrast to human, most species carry cholesterol mainly in HDL particles. In mice and rats, LDL cholesterol is lower than HDL cholesterol. Rats have a strong overlap between both LDL and HDL particles. Pigs have a lipoprotein profile comparable to human characterized by high LDL cholesterol [adapted from [95]] of the heart and coronary circulation is similar to that of humans, atherosclerotic plaques mainly form in the thoracic aorta, and coronary lesions are usually restricted to the left coronary arterial trunks [78].

Pigs are susceptible to atherosclerosis upon hypercholesterolemia-induced by a high cholesterol diet, usually containing cholate to prevent the production of bile from cholesterol [3, 51]. A combination of high cholesterol diet and induced vascular injury is usually required to reduce the time for plaque development. Vascular injury can be achieved through methods such as percutaneous intramural injection of cholesteryl esters and human oxLDL, guidewire-induced injury, balloon inflation or partial vessel ligation [61, 62, 194]. In addition, pigs are anatomically and phylogenetically closer to humans compared to other models, and similarly are omnivorous. Finally, the size of the heart and coronary arteries makes them adequately suited to study atherosclerosis. Indeed, thrombus formation, plaque ruptures, IR injury and the fact that atherosclerosis develops in older pigs, provides a comparable platform to study the human disease and test therapeutic interventions that can be used in the clinic $[10,167,185]$.

\section{Summary and conclusions}

In the context of atherosclerosis, many studies utilize mouse models due to their small size, low associated costs and a plethora of available transgenic strains. Although several studies have investigated infarct size in these models, the efficacy of cardioprotective strategies have not yet been studied extensively. There are several factors to consider when choosing the ideal model as summarised in Table 1. The lack of coronary artery lesions impacting coronary artery function in most mouse models, make it difficult to be certain that therapeutic interventions can be translated into the clinic. In addition, the lipoprotein profiles and mechanisms of metabolism are an important aspect that affects disease progression and must also be considered in the chosen model. Of the most widely studied strains, $A p o E^{-/-}$mice and $L D L R^{-/-}$mice are popular choices for the study of atherosclerosis due to their susceptibility to developing atherosclerotic lesions. However, the atherosclerotic plaques are mainly located in the aorta and the surrounding regions, and no evidence of coronary artery dysfunction in these models has been reported. Despite their limitations, the transgenic mouse models reviewed here contribute to the overall corpus of knowledge on the effect that these genetic mutations have on cardioprotection in mouse models. Whether the effects observed are strictly due to atherosclerotic changes in the heart, or, as seems more likely, other functions of the proteins in the cardiovascular system, remains to be clearly determined. A better model for coronary artery 
atherosclerosis appears to involve $S R B I$. Though not without its caveats, $S R B I^{-/-} ; L D L R^{-/-}$mice provide a platform where coronary artery plaque development occurs on a normal diet in a relatively short time. This enables the study of IR and cardioprotection in a model that, it is hoped, more accurately reflects the response of the cardiac patient.

In conclusion, the huge number of cardioprotective compounds and treatments that have been shown over the past decades to be effective in mice, despite the lack of successful translation to animals, may be a sign of the bias inherent in the commonly used experimental model of mouse infarction. In order to discover cardioprotective strategies that are not only effective in mice but can be translated successfully to benefit STEMI patients, we suggest that it is important to use mouse models of atherosclerosis that exhibit lesions in the coronary arteries. Ideally, these lesions would result in vascular dysfunction, as is seen in patients, since this dysfunction is likely to have a major impact on the induction and effectiveness of certain cardioprotective modalities. In IR studies with infarct size as an endpoint, ischaemia is artificially induced by coronary ligation, so plaque vulnerability and rupture are not technically essential for the model. Similarly, it may not be crucially important that plaque morphology differs somewhat between mice and humans. On the other hand, if plaque rupture and micro-embolism $d o$ occur in the atherosclerotic mouse model, it might better mimic the contribution that MVO makes to IR injury. However, the level of spontaneous plaque rupture and myocardial infarction should not be excessive, or it could interfere with the measurement of the experimentally induced infarct. Although the study of atherosclerosis and coronary function in mouse coronary arteries is challenging, we believe these studies are necessary for the future development of ideal IR models in mice.

Funding SMD acknowledges the support of National Institute of Health Research (NIHR) Biomedical Research Council [BRC233/ CM/SD/101320] and the British Heart Foundation [PG/19/51/34493].

\section{Compliance with ethical standards}

\section{Conflict of interest None.}

Open Access This article is licensed under a Creative Commons Attribution 4.0 International License, which permits use, sharing, adaptation, distribution and reproduction in any medium or format, as long as you give appropriate credit to the original author(s) and the source, provide a link to the Creative Commons licence, and indicate if changes were made. The images or other third party material in this article are included in the article's Creative Commons licence, unless indicated otherwise in a credit line to the material. If material is not included in the article's Creative Commons licence and your intended use is not permitted by statutory regulation or exceeds the permitted use, you will need to obtain permission directly from the copyright holder. To view a copy of this licence, visit http://creativecommons.org/licenses/by/4.0/.

\section{References}

1. Acton S, Rigotti A, Landschulz KT, Xu S, Hobbs HH, Krieger M (1996) Identification of scavenger receptor SR-BI as a high density lipoprotein receptor. Science 271:518-520. https://doi. org/10.1126/science.271.5248.518

2. Al-Jarallah A, Trigatti BL (2010) A role for the scavenger receptor, class B type I in high density lipoprotein dependent activation of cellular signaling pathways. Biochim Biophys Acta 1801:1239-1248. https://doi.org/10.1016/j.bbalip.2010.08.006

3. Al-Mashhadi RH, Sorensen CB, Kragh PM, Christoffersen C, Mortensen MB, Tolbod LP, Thim T, Du Y, Li J, Liu Y, Moldt B, Schmidt M, Vajta G, Larsen T, Purup S, Bolund L, Nielsen LB, Callesen H, Falk E, Mikkelsen JG, Bentzon JF (2013) Familial hypercholesterolemia and atherosclerosis in cloned minipigs created by DNA transposition of a human PCSK9 gain-of-function mutant. Sci Transl Med 5:166ra161. https://doi.org/10.1126/scitr anslmed.3004853

4. Alonso F, Boittin FX, Beny JL, Haefliger JA (2010) Loss of connexin 40 is associated with decreased endothelium-dependent relaxations and eNOS levels in the mouse aorta. Am J Physiol Heart Circ Physiol 299:H1365-1373. https://doi.org/10.1152/ ajpheart.00029.2010

5. Ammirati E, Moroni F, Magnoni M, Camici PG (2015) The role of $\mathrm{T}$ and $\mathrm{B}$ cells in human atherosclerosis and atherothrombosis. Clin Exp Immunol 179:173-187. https://doi.org/10.1111/ cei. 12477

6. Andreadou I, Schulz R, Badimon L, Adameova A, Kleinbongard P, Lecour S, Nikolaou PE, Falcao-Pires I, Vilahur G, Woudberg N, Heusch G, Ferdinandy P (2019) Hyperlipidaemia and cardioprotection: animal models for translational studies. Br J Pharmacol. https://doi.org/10.1111/bph.14931

7. Arnon R, Sehayek E, Vogel T, Eisenberg S (1991) Effects of exogenous apo E-3 and of cholesterol-enriched meals on the cellular metabolism of human chylomicrons and their remnants. Biochim Biophys Acta 1085:336-342. https://doi. org/10.1016/0005-2760(91)90138-8

8. Ason B, van der Hoorn JW, Chan J, Lee E, Pieterman EJ, Nguyen KK, Di M, Shetterly S, Tang J, Yeh WC, Schwarz M, Jukema JW, Scott R, Wasserman SM, Princen HM, Jackson S (2014) PCSK9 inhibition fails to alter hepatic LDLR, circulating cholesterol, and atherosclerosis in the absence of ApoE. J Lipid Res 55:2370-2379. https://doi.org/10.1194/jlr.M053207

9. Atkins KB, Prezkop A, Park JL, Saha J, Duquaine D, Charron MJ, Olson AL, Brosius FC 3rd (2007) Preserved expression of GLUT4 prevents enhanced agonist-induced vascular reactivity and MYPT1 phosphorylation in hypertensive mouse aorta. Am J Physiol Heart Circ Physiol 293:H402-408. https://doi. org/10.1152/ajpheart.00854.2006

10. Baehr A, Klymiuk N, Kupatt C (2019) Evaluating novel targets of ischemia reperfusion injury in pig models. Int J Mol Sci. https ://doi.org/10.3390/ijms20194749

11. Baltgalvis KA, White K, Li W, Claypool MD, Lang W, Alcantara R, Singh BK, Friera AM, McLaughlin J, Hansen D, McCaughey K, Nguyen H, Smith IJ, Godinez G, Shaw SJ, Goff D, Singh R, Markovtsov V, Sun TQ, Jenkins Y, Uy G, Li Y, Pan A, Gururaja T, Lau D, Park G, Hitoshi Y, Payan DG, Kinsella TM (2014) Exercise performance and peripheral vascular insufficiency improve with AMPK activation in high-fat diet-fed mice. Am J Physiol Heart Circ Physiol 306:H1128-1145. https://doi. org/10.1152/ajpheart.00839.2013

12. Barter PJ, Baker PW, Rye KA (2002) Effect of high-density lipoproteins on the expression of adhesion molecules in endothelial cells. Curr Opin Lipidol 13:285-288. https://doi. org/10.1097/00041433-200206000-00008 
13. Barthwal MK, Anzinger JJ, Xu Q, Bohnacker T, Wymann MP, Kruth HS (2013) Fluid-phase pinocytosis of native low density lipoprotein promotes murine M-CSF differentiated macrophage foam cell formation. PLoS ONE 8:e58054. https://doi. org/10.1371/journal.pone.0058054

14. Basalay MV, Yellon DM, Davidson SM (2020) Targeting myocardial ischaemic injury in the absence of reperfusion. Basic Res Cardiol. In Press

15. Bentzon JF, Falk E (2010) Atherosclerotic lesions in mouse and man: is it the same disease? Curr Opin Lipidol 21:434-440. https ://doi.org/10.1097/MOL.0b013e32833ded6a

16. Bibli SI, Papapetropoulos A, Iliodromitis EK, Daiber A, Randriamboavonjy V, Steven S, Brouckaert P, Chatzianastasiou A, Kypreos KE, Hausenloy DJ, Fleming I, Andreadou I (2019) Nitroglycerine limits infarct size through S-nitrosation of cyclophilin D: a novel mechanism for an old drug. Cardiovasc Res 115:625-636. https://doi.org/10.1093/cvr/cvy222

17. Boren J, Williams KJ (2016) The central role of arterial retention of cholesterol-rich apolipoprotein-B-containing lipoproteins in the pathogenesis of atherosclerosis: a triumph of simplicity. Curr Opin Lipidol 27:473-483. https://doi.org/10.1097/MOL.00000 00000000330

18. Botker HE, Hausenloy D, Andreadou I, Antonucci S, Boengler K, Davidson SM, Deshwal S, Devaux Y, Di Lisa F, Di Sante M, Efentakis P, Femmino S, Garcia-Dorado D, Giricz Z, Ibanez B, Iliodromitis E, Kaludercic N, Kleinbongard P, Neuhauser M, Ovize M, Pagliaro P, Rahbek-Schmidt M, Ruiz-Meana M, Schluter KD, Schulz R, Skyschally A, Wilder C, Yellon DM, Ferdinandy P, Heusch G (2018) Practical guidelines for rigor and reproducibility in preclinical and clinical studies on cardioprotection. Basic Res Cardiol 113:39. https://doi.org/10.1007/ s00395-018-0696-8

19. Bracken MB (2009) Why animal studies are often poor predictors of human reactions to exposure. J R Soc Med 102:120 122. https://doi.org/10.1258/jrsm.2008.08k033

20. Braun A, Trigatti BL, Post MJ, Sato K, Simons M, Edelberg JM, Rosenberg RD, Schrenzel M, Krieger M (2002) Loss of SR-BI expression leads to the early onset of occlusive atherosclerotic coronary artery disease, spontaneous myocardial infarctions, severe cardiac dysfunction, and premature death in apolipoprotein E-deficient mice. Circ Res 90:270-276. https:// doi.org/10.1161/hh0302.104462

21. Breslow JL (1996) Mouse models of atherosclerosis. Science 272:685-688. https://doi.org/10.1126/science.272.5262.685

22. Bromage DI, Pickard JM, Rossello X, Ziff OJ, Burke N, Yellon DM, Davidson SM (2017) Remote ischaemic conditioning reduces infarct size in animal in vivo models of ischaemiareperfusion injury: a systematic review and meta-analysis. Cardiovasc Res 113:288-297. https://doi.org/10.1093/cvr/cvw219

23. Brown MS, Goldstein JL (1986) A receptor-mediated pathway for cholesterol homeostasis. Science 232:34-47. https://doi. org/10.1126/science. 3513311

24. Calara F, Silvestre M, Casanada F, Yuan N, Napoli C, Palinski W (2001) Spontaneous plaque rupture and secondary thrombosis in apolipoprotein E-deficient and LDL receptor-deficient mice. J Pathol 195:257-263. https://doi.org/10.1002/path.915

25. Chang WT, Fisch S, Chen M, Qiu Y, Cheng S, Liao R (2015) Ultrasound based assessment of coronary artery flow and coronary flow reserve using the pressure overload model in mice. J Vis Exp. https://doi.org/10.3791/52598

26. Chen WR, Chen YD, Tian F, Yang N, Cheng LQ, Hu SY, Wang J, Yang JJ, Wang SF, Gu XF (2016) Effects of liraglutide on reperfusion injury in patients with ST-segment-elevation myocardial infarction. Circ Cardiovasc Imaging. https://doi. org/10.1161/CIRCIMAGING.116.005146
27. Coleman R, Hayek T, Keidar S, Aviram M (2006) A mouse model for human atherosclerosis: long-term histopathological study of lesion development in the aortic arch of apolipoprotein E-deficient (E0) mice. Acta Histochem 108:415-424. https:// doi.org/10.1016/j.acthis.2006.07.002

28. Covey SD, Krieger M, Wang W, Penman M, Trigatti BL (2003) Scavenger receptor class B type I-mediated protection against atherosclerosis in LDL receptor-negative mice involves its expression in bone marrow-derived cells. Arterioscler Thromb Vasc Biol 23:1589-1594. https://doi.org/10.1161/01. ATV.0000083343.19940.A0

29. Curry FE, Adamson RH (2012) Endothelial glycocalyx: permeability barrier and mechanosensor. Ann Biomed Eng 40:828839. https://doi.org/10.1007/s10439-011-0429-8

30. Daugherty A, Tall AR, Daemen M, Falk E, Fisher EA, GarciaCardena G, Lusis AJ, Owens AP 3rd, Rosenfeld ME, Virmani $\mathrm{R}$, American Heart Association Council on Arteriosclerosis T, Vascular B, Council on Basic Cardiovascular S (2017) Recommendation on design, execution, and reporting of animal atherosclerosis studies: a scientific statement from the American heart association. Circ Res 121:e53-e79. https:// doi.org/10.1161/RES.0000000000000169

31. Davidson SM, Adameova A, Barile L, Cabrera-Fuentes HA, Lazou A, Pagliaro P, Stenslokken KO, Garcia-Dorado D, Action E-CC (2020) Mitochondrial and mitochondrial-independent pathways of myocardial cell death during ischaemia and reperfusion injury. J Cell Mol Med 24:3795-3806. https ://doi.org/10.1111/jcmm.15127

32. Davidson SM, Ferdinandy P, Andreadou I, Botker HE, Heusch G, Ibanez B, Ovize M, Schulz R, Yellon DM, Hausenloy DJ, GarciaDorado D, Action CC (2019) Multitarget strategies to reduce myocardial ischemia/reperfusion injury: JACC review topic of the week. J Am Coll Cardiol 73:89-99. https://doi.org/10.1016/j. jacc.2018.09.086

33. DeWood MA, Spores J, Notske R, Mouser LT, Burroughs R, Golden MS, Lang HT (1980) Prevalence of total coronary occlusion during the early hours of transmural myocardial infarction. N Engl J Med 303:897-902. https://doi.org/10.1056/NEJM1 98010163031601

34. DeWood MA, Stifter WF, Simpson CS, Spores J, Eugster GS, Judge TP, Hinnen ML (1986) Coronary arteriographic findings soon after non-Q-wave myocardial infarction. N Engl J Med 315:417-423. https://doi.org/10.1056/NEJM198608143150703

35. Dick SA, Macklin JA, Nejat S, Momen A, Clemente-Casares X, Althagafi MG, Chen J, Kantores C, Hosseinzadeh S, Aronoff L, Wong A, Zaman R, Barbu I, Besla R, Lavine KJ, Razani B, Ginhoux F, Husain M, Cybulsky MI, Robbins CS, Epelman S (2019) Self-renewing resident cardiac macrophages limit adverse remodeling following myocardial infarction. Nat Immunol 20:29-39. https://doi.org/10.1038/s41590-018-0272-2

36. Dirksen MT, Laarman GJ, Simoons ML, Duncker DJ (2007) Reperfusion injury in humans: a review of clinical trials on reperfusion injury inhibitory strategies. Cardiovasc Res 74:343-355. https://doi.org/10.1016/j.cardiores.2007.01.014

37. Edland F, Wergeland A, Kopperud R, Asrud KS, Hoivik EA, Witso SL, Æsøy R, Madsen L, Kristiansen K, Bakke M, Doskeland SO, Jonassen AK (2016) Long-term consumption of an obesogenic high fat diet prior to ischemia-reperfusion mediates cardioprotection via Epac1-dependent signaling. Nutr Metab (Lond) 13:87. https://doi.org/10.1186/s12986-016-0147-1

38. Efentakis P, Rizakou A, Christodoulou E, Chatzianastasiou A, Lopez MG, Leon R, Balafas E, Kadoglou NPE, Tseti I, Skaltsa H, Kostomitsopoulos N, Iliodromitis EK, Valsami G, Andreadou I (2017) Saffron (Crocus sativus) intake provides nutritional preconditioning against myocardial ischemia-reperfusion injury in Wild Type and ApoE((-/-)) mice: involvement of Nrf2 
activation. Nutr Metab Cardiovasc Dis 27:919-929. https://doi. org/10.1016/j.numecd.2017.08.005

39. Ellis A, Cheng ZJ, Li Y, Jiang YF, Yang J, Pannirselvam M, Ding H, Hollenberg MD, Triggle CR (2008) Effects of a Western diet versus high glucose on endothelium-dependent relaxation in murine micro- and macro-vasculature. Eur J Pharmacol 601:111-117. https://doi.org/10.1016/j.ejphar.2008.10.042

40. Elsman P, van't Hof AW, Hoorntje JC, de Boer MJ, Borm GF, Suryapranata H, Ottervanger JP, Gosselink AT, Dambrink JH, Zijlstra F (2006) Effect of coronary occlusion site on angiographic and clinical outcome in acute myocardial infarction patients treated with early coronary intervention. Am J Cardiol 97:1137-1141. https://doi.org/10.1016/j.amjcard.2005.11.027

41. Emini Veseli B, Perrotta P, De Meyer GRA, Roth L, Van der Donckt C, Martinet W, De Meyer GRY (2017) Animal models of atherosclerosis. Eur J Pharmacol 816:3-13. https://doi. org/10.1016/j.ejphar.2017.05.010

42. Fan J, Kitajima S, Watanabe T, Xu J, Zhang J, Liu E, Chen YE (2015) Rabbit models for the study of human atherosclerosis: from pathophysiological mechanisms to translational medicine. Pharmacol Ther 146:104-119. https://doi.org/10.1016/j.pharm thera.2014.09.009

43. Ferdinandy P, Hausenloy DJ, Heusch G, Baxter GF, Schulz R (2014) Interaction of risk factors, comorbidities, and comedications with ischemia/reperfusion injury and cardioprotection by preconditioning, postconditioning, and remote conditioning. Pharmacol Rev 66:1142-1174. https://doi.org/10.1124/ pr. 113.008300

44. Fernandez B, Duran AC, Fernandez MC, Fernandez-Gallego T, Icardo JM, Sans-Coma V (2008) The coronary arteries of the C57BL/6 mouse strains: implications for comparison with mutant models. J Anat 212:12-18. https://doi.org/10.111 1/j.1469-7580.2007.00838.x

45. Fliss H, Gattinger D (1996) Apoptosis in ischemic and reperfused rat myocardium. Circ Res 79:949-956. https://doi. org/10.1161/01.res.79.5.949

46. Forstermann U, Sessa WC (2012) Nitric oxide synthases: regulation and function. Eur Heart J 33(829-837):837a-837d. https ://doi.org/10.1093/eurheartj/ehr304

47. Fuller M, Dadoo O, Serkis V, Abutouk D, MacDonald M, Dhingani N, Macri J, Igdoura SA, Trigatti BL (2014) The effects of diet on occlusive coronary artery atherosclerosis and myocardial infarction in scavenger receptor class B, type 1/low-density lipoprotein receptor double knockout mice. Arterioscler Thromb Vasc Biol 34:2394-2403. https://doi. org/10.1161/ATVBAHA.114.304200

48. Galis ZS, Sukhova GK, Lark MW, Libby P (1994) Increased expression of matrix metalloproteinases and matrix degrading activity in vulnerable regions of human atherosclerotic plaques. J Clin Invest 94:2493-2503. https://doi.org/10.1172/ JCI117619

49. Galkina E, Kadl A, Sanders J, Varughese D, Sarembock IJ, Ley K (2006) Lymphocyte recruitment into the aortic wall before and during development of atherosclerosis is partially $\mathrm{L}$-selectin dependent. J Exp Med 203:1273-1282. https://doi.org/10.1084/ jem.20052205

50. Galkina E, Ley K (2009) Immune and inflammatory mechanisms of atherosclerosis (*). Annu Rev Immunol 27:165-197. https:// doi.org/10.1146/annurev.immunol.021908.132620

51. Getz GS, Reardon CA (2012) Animal models of atherosclerosis. Arterioscler Thromb Vasc Biol 32:1104-1115. https://doi. org/10.1161/ATVBAHA.111.237693

52. Getz GS, Reardon CA (2009) Apoprotein E as a lipid transport and signaling protein in the blood, liver, and artery wall. J Lipid Res 50(Suppl):S156-161. https://doi.org/10.1194/jlr.R8000 58-JLR200
53. Getz GS, Reardon CA (2006) Diet and murine atherosclerosis. Arterioscler Thromb Vasc Biol 26:242-249. https://doi. org/10.1161/01.ATV.0000201071.49029.17

54. Gibson CM, Kirtane AJ, Murphy SA, Karha J, Cannon CP, Giugliano RP, Roe MT, Harrington RA, Ohman EM, Antman EM (2003) Distance from the coronary ostium to the culprit lesion in acute ST-elevation myocardial infarction and its implications regarding the potential prevention of proximal plaque rupture. J Thromb Thrombolysis 15:189-196. https://doi.org/10.1023/ B:THRO.0000011374.60110.bc

55. Girod WG, Jones SP, Sieber N, Aw TY, Lefer DJ (1999) Effects of hypercholesterolemia on myocardial ischemia-reperfusion injury in LDL receptor-deficient mice. Arterioscler Thromb Vasc Biol 19:2776-2781. https://doi.org/10.1161/01.atv.19.11.2776

56. Godecke A, Ziegler M, Ding Z, Schrader J (2002) Endothelial dysfunction of coronary resistance vessels in apoE-/- mice involves NO but not prostacyclin-dependent mechanisms. Cardiovasc Res 53:253-262. https://doi.org/10.1016/s0008 -6363(01)00432-1

57. Goettsch C, Hutcheson JD, Hagita S, Rogers MA, Creager MD, Pham T, Choi J, Mlynarchik AK, Pieper B, Kjolby M, Aikawa M, Aikawa E (2016) A single injection of gain-of-function mutant PCSK9 adeno-associated virus vector induces cardiovascular calcification in mice with no genetic modification. Atherosclerosis 251:109-118. https://doi.org/10.1016/j.atherosclerosis .2016.06.011

58. Golino P, Maroko PR, Carew TE (1987) The effect of acute hypercholesterolemia on myocardial infarct size and the noreflow phenomenon during coronary occlusion-reperfusion. Circulation 75:292-298. https://doi.org/10.1161/01.cir.75.1.292

59. Gordon DJ, Rifkind BM (1989) High-density lipoprotein-the clinical implications of recent studies. N Engl J Med 321:13111316. https://doi.org/10.1056/nejm198911093211907

60. Gori T (2020) Exogenous NO therapy for the treatment and prevention of atherosclerosis. Int J Mol Sci. https://doi.org/10.3390/ ijms 21082703

61. Granada JF, Moreno PR, Burke AP, Schulz DG, Raizner AE, Kaluza GL (2005) Endovascular needle injection of cholesteryl linoleate into the arterial wall produces complex vascular lesions identifiable by intravascular ultrasound: early development in a porcine model of vulnerable plaque. Coron Artery Dis 16:217224. https://doi.org/10.1097/00019501-200506000-00002

62. Granada JF, Wallace-Bradley D, Win HK, Alviar CL, Builes A, Lev EI, Barrios R, Schulz DG, Raizner AE, Kaluza GL (2007) In vivo plaque characterization using intravascular ultrasoundvirtual histology in a porcine model of complex coronary lesions. Arterioscler Thromb Vasc Biol 27:387-393. https://doi. org/10.1161/01.ATV.0000253907.51681.0e

63. Groot PH, van Vlijmen BJ, Benson GM, Hofker MH, Schiffelers R, Vidgeon-Hart M, Havekes LM (1996) Quantitative assessment of aortic atherosclerosis in APOE*3 Leiden transgenic mice and its relationship to serum cholesterol exposure. Arterioscler Thromb Vasc Biol 16:926-933. https://doi.org/10.1161/01. atv.16.8.926

64. Guo L, Chen M, Song Z, Daugherty A, Li XA (2011) C323 of SR-BI is required for SR-BI-mediated HDL binding and cholesteryl ester uptake. J Lipid Res 52:2272-2278. https://doi. org/10.1194/jlr.M019091

65. Haase CL, Tybjaerg-Hansen A, Qayyum AA, Schou J, Nordestgaard BG, Frikke-Schmidt R (2012) LCAT, HDL cholesterol and ischemic cardiovascular disease: a Mendelian randomization study of HDL cholesterol in 54,500 individuals. J Clin Endocrinol Metab 97:E248-256. https://doi.org/10.1210/jc.2011-1846

66. Halcox JP, Schenke WH, Zalos G, Mincemoyer R, Prasad A, Waclawiw MA, Nour KR, Quyyumi AA (2002) Prognostic value of coronary vascular endothelial dysfunction. Circulation 
106:653-658. https://doi.org/10.1161/01.cir.0000025404.78001 .d8

67. Halvorsen B, Otterdal K, Dahl TB, Skjelland M, Gullestad L, Oie E, Aukrust P (2008) Atherosclerotic plaque stability-what determines the fate of a plaque? Prog Cardiovasc Dis 51:183-194. https://doi.org/10.1016/j.pcad.2008.09.001

68. Hausenloy DJ, Barrabes JA, Botker HE, Davidson SM, Di Lisa F, Downey J, Engstrom T, Ferdinandy P, Carbrera-Fuentes HA, Heusch G, Ibanez B, Iliodromitis EK, Inserte J, Jennings R, Kalia N, Kharbanda R, Lecour S, Marber M, Miura T, Ovize M, PerezPinzon MA, Piper HM, Przyklenk K, Schmidt MR, Redington A, Ruiz-Meana M, Vilahur G, Vinten-Johansen J, Yellon DM, Garcia-Dorado D (2016) Ischaemic conditioning and targeting reperfusion injury: a 30 year voyage of discovery. Basic Res Cardiol 111:70. https://doi.org/10.1007/s00395-016-0588-8

69. Hausenloy DJ, Garcia-Dorado D, Botker HE, Davidson SM, Downey J, Engel FB, Jennings R, Lecour S, Leor J, Madonna R, Ovize M, Perrino C, Prunier F, Schulz R, Sluijter JPG, Van Laake LW, Vinten-Johansen J, Yellon DM, Ytrehus K, Heusch G, Ferdinandy P (2017) Novel targets and future strategies for acute cardioprotection: position paper of the European society of cardiology working group on cellular biology of the heart. Cardiovasc Res 113:564-585. https://doi.org/10.1093/cvr/cvx049

70. Hausenloy DJ, Kharbanda RK, Moller UK, Ramlall M, Aaroe J, Butler R, Bulluck H, Clayton T, Dana A, Dodd M, Engstrom T, Evans R, Lassen JF, Christensen EF, Garcia-Ruiz JM, Gorog DA, Hjort J, Houghton RF, Ibanez B, Knight R, Lippert FK, Lonborg JT, Maeng M, Milasinovic D, More R, Nicholas JM, Jensen LO, Perkins A, Radovanovic N, Rakhit RD, Ravkilde J, Ryding AD, Schmidt MR, Riddervold IS, Sorensen HT, Stankovic G, Varma M, Webb I, Terkelsen CJ, Greenwood JP, Yellon DM, Botker HE, Investigators C-E-P (2019) Effect of remote ischaemic conditioning on clinical outcomes in patients with acute myocardial infarction (CONDI-2/ERIC-PPCI): a single-blind randomised controlled trial. Lancet 394:1415-1424. https://doi.org/10.1016/ S0140-6736(19)32039-2

71. Hausenloy DJ, Yellon DM (2016) Ischaemic conditioning and reperfusion injury. Nat Rev Cardiol 13:193-209. https://doi. org/10.1038/nrcardio.2016.5

72. Herman MP, Sukhova GK, Libby P, Gerdes N, Tang N, Horton DB, Kilbride M, Breitbart RE, Chun M, Schonbeck U (2001) Expression of neutrophil collagenase (matrix metalloproteinase-8) in human atheroma: a novel collagenolytic pathway suggested by transcriptional profiling. Circulation 104:1899-1904. https://doi.org/10.1161/hc4101.097419

73. Hermann S, Kuhlmann MT, Starsichova A, Eligehausen S, Schafers K, Stypmann J, Tiemann K, Levkau B, Schafers M (2016) Imaging reveals the connection between spontaneous coronary plaque ruptures, atherothrombosis, and myocardial infarctions in HypoE/SRBI-/- mice. J Nucl Med 57:1420-1427. https://doi. org/10.2967/jnumed.115.171132

74. Heusch G (2016) The coronary circulation as a target of cardioprotection. Circ Res 118:1643-1658. https://doi.org/10.1161/ CIRCRESAHA.116.308640

75. Heusch G (2019) Coronary microvascular obstruction: the new frontier in cardioprotection. Basic Res Cardiol 114:45. https:// doi.org/10.1007/s00395-019-0756-8

76. Heusch G (2017) Critical issues for the translation of cardioprotection. Circ Res 120:1477-1486. https://doi.org/10.1161/CIRCR ESAHA.117.310820

77. Hinder LM, Vincent AM, Hayes JM, McLean LL, Feldman EL (2013) Apolipoprotein E knockout as the basis for mouse models of dyslipidemia-induced neuropathy. Exp Neurol 239:102-110. https://doi.org/10.1016/j.expneurol.2012.10.002

78. Hirata M, Watanabe T (1988) Regression of atherosclerosis in normotensive and hypertensive rabbits. A quantitative analysis of cholesterol-induced aortic and coronary lesions with an imageprocessing system. Acta Pathol Jpn 38:559-575

79. Hoekstra M, Van Eck M, Korporaal SJ (2012) Genetic studies in mice and humans reveal new physiological roles for the high-density lipoprotein receptor scavenger receptor class B type I. Curr Opin Lipidol 23:127-132. https://doi.org/10.1097/ MOL.0b013e3283508c09

80. Hu W, Polinsky P, Sadoun E, Rosenfeld ME, Schwartz SM (2005) Atherosclerotic lesions in the common coronary arteries of ApoE knockout mice. Cardiovasc Pathol 14:120-125. https:// doi.org/10.1016/j.carpath.2005.02.004

81. Ignatowski AC (1908) Influence of animal food on the organsim of rabbits. Izvest Imper Voennomed Akad St Petersburg $16: 154-173$

82. Iiyama K, Hajra L, Iiyama M, Li H, DiChiara M, Medoff BD, Cybulsky MI (1999) Patterns of vascular cell adhesion molecule-1 and intercellular adhesion molecule-1 expression in rabbit and mouse atherosclerotic lesions and at sites predisposed to lesion formation. Circ Res 85:199-207. https://doi. org/10.1161/01.res.85.2.199

83. Innis-Whitehouse W, Li X, Brown WV, Le NA (1998) An efficient chromatographic system for lipoprotein fractionation using whole plasma. J Lipid Res 39:679-690

84. Ishibashi S, Brown MS, Goldstein JL, Gerard RD, Hammer RE, Herz J (1993) Hypercholesterolemia in low density lipoprotein receptor knockout mice and its reversal by adenovirusmediated gene delivery. J Clin Invest 92:883-893. https://doi. org/10.1172/JCI116663

85. Ishibashi S, Goldstein JL, Brown MS, Herz J, Burns DK (1994) Massive xanthomatosis and atherosclerosis in cholesterol-fed low density lipoprotein receptor-negative mice. J Clin Invest 93:1885-1893. https://doi.org/10.1172/JCI117179

86. Ishibashi S, Herz J, Maeda N, Goldstein JL, Brown MS (1994) The two-receptor model of lipoprotein clearance: tests of the hypothesis in "knockout" mice lacking the low density lipoprotein receptor, apolipoprotein $\mathrm{E}$, or both proteins. Proc Natl Acad Sci U S A 91:4431-4435. https://doi.org/10.1073/ pnas.91.10.4431

87. Ishida T, Choi SY, Kundu RK, Spin J, Yamashita T, Hirata K, Kojima Y, Yokoyama M, Cooper AD, Quertermous T (2004) Endothelial lipase modulates susceptibility to atherosclerosis in apolipoprotein-E-deficient mice. J Biol Chem 279:4508545092. https://doi.org/10.1074/jbc.M406360200

88. Jawien J, Nastalek P, Korbut R (2004) Mouse models of experimental atherosclerosis. J Physiol Pharmacol 55:503-517

89. Ji Y, Jian B, Wang N, Sun Y, Moya ML, Phillips MC, Rothblat GH, Swaney JB, Tall AR (1997) Scavenger receptor BI promotes high density lipoprotein-mediated cellular cholesterol efflux. J Biol Chem 272:20982-20985. https://doi.org/10.1074/ jbc.272.34.20982

90. Ji ZS, Dichek HL, Miranda RD, Mahley RW (1997) Heparan sulfate proteoglycans participate in hepatic lipaseand apolipoprotein E-mediated binding and uptake of plasma lipoproteins, including high density lipoproteins. J Biol Chem 272:3128531292. https://doi.org/10.1074/jbc.272.50.31285

91. Jiang J, Valen G, Tokuno S, Thoren P, Pernow J (2000) Endothelial dysfunction in atherosclerotic mice: improved relaxation by combined supplementation with L-arginine-tetrahydrobiopterin and enhanced vasoconstriction by endothelin. Br J Pharmacol 131:1255-1261. https://doi.org/10.1038/ sj.bjp.0703705

92. Jin PY, Zhang HS, Guo XY, Liang WF, Han QF (2014) Glucose-insulin-potassium therapy in patients with acute coronary syndrome: a meta-analysis of randomized controlled trials. BMC Cardiovasc Disord 14:169. https://doi. org/10.1186/1471-2261-14-169 
93. Johnson J, Carson K, Williams H, Karanam S, Newby A, Angelini G, George S, Jackson C (2005) Plaque rupture after short periods of fat feeding in the apolipoprotein E-knockout mouse: model characterization and effects of pravastatin treatment. Circulation 111:1422-1430. https://doi.org/10.1161/01.CIR.00001 58435.98035.8D

94. Johnson WJ, Mahlberg FH, Rothblat GH, Phillips MC (1991) Cholesterol transport between cells and high-density lipoproteins. Biochim Biophys Acta 1085:273-298. https://doi. org/10.1016/0005-2760(91)90132-2

95. Kaabia Z, Poirier J, Moughaizel M, Aguesse A, Billon-Crossouard S, Fall F, Durand M, Dagher E, Krempf M, Croyal M (2018) Plasma lipidomic analysis reveals strong similarities between lipid fingerprints in human, hamster and mouse compared to other animal species. Sci Rep 8:15893. https://doi. org/10.1038/s41598-018-34329-3

96. Kajstura J, Cheng W, Reiss K, Clark WA, Sonnenblick EH, Krajewski S, Reed JC, Olivetti G, Anversa P (1996) Apoptotic and necrotic myocyte cell deaths are independent contributing variables of infarct size in rats. Lab Invest 74:86-107

97. Karha J, Murphy SA, Kirtane AJ, de Lemos JA, Aroesty JM, Cannon CP, Antman EM, Braunwald E, Gibson CM, Group TS (2003) Evaluation of the association of proximal coronary culprit artery lesion location with clinical outcomes in acute myocardial infarction. Am J Cardiol 92:913-918. https://doi.org/10.1016/ s0002-9149(03)00969-x

98. Kimura T, Kobiyama K, Winkels H, Tse K, Miller J, Vassallo M, Wolf D, Ryden C, Orecchioni M, Dileepan T, Jenkins MK, James EA, Kwok WW, Hanna DB, Kaplan RC, Strickler HD, Durkin HG, Kassaye SG, Karim R, Tien PC, Landay AL, Gange SJ, Sidney J, Sette A, Ley K (2018) Regulatory CD4(+) T cells recognize major histocompatibility complex class II molecule-restricted peptide epitopes of apolipoprotein B. Circulation 138:1130-1143. https://doi.org/10.1161/CIRCU LATIONAHA.117.031420

99. Kleinbongard P, Schleiger A, Heusch G (2013) Characterization of vasomotor responses in different vascular territories of C57BL/6J mice. Exp Biol Med (Maywood) 238:1180-1191. https://doi.org/10.1177/1535370213502621

100. Kloner RA, Nesto RW (2008) Glucose-insulin-potassium for acute myocardial infarction: continuing controversy over cardioprotection. Circulation 117:2523-2533. https://doi. org/10.1161/CIRCULATIONAHA.107.697979

101. Knowles JW, Maeda N (2000) Genetic modifiers of atherosclerosis in mice. Arterioscler Thromb Vasc Biol 20:2336-2345. https://doi.org/10.1161/01.atv.20.11.2336

102. Kooistra T, Verschuren L, de Vries-van der Weij J, Koenig W, Toet K, Princen HM, Kleemann R (2006) Fenofibrate reduces atherogenesis in ApoE*3Leiden mice: evidence for multiple antiatherogenic effects besides lowering plasma cholesterol. Arterioscler Thromb Vasc Biol 26:2322-2330. https://doi. org/10.1161/01.ATV.0000238348.05028.14

103. Koshinuma S, Miyamae M, Kaneda K, Kotani J, Figueredo VM (2014) Combination of necroptosis and apoptosis inhibition enhances cardioprotection against myocardial ischemia-reperfusion injury. J Anesth 28:235-241. https://doi.org/10.1007/ s00540-013-1716-3

104. Krieger M (1999) Charting the fate of the "good cholesterol": identification and characterization of the high-density lipoprotein receptor SR-BI. Annu Rev Biochem 68:523-558. https:// doi.org/10.1146/annurev.biochem.68.1.523

105. Krimbou L, Denis M, Haidar B, Carrier M, Marcil M, Genest J Jr (2004) Molecular interactions between apoE and ABCA1: impact on apoE lipidation. J Lipid Res 45:839-848. https://doi. org/10.1194/jlr.M300418-JLR200
106. Landschulz KT, Pathak RK, Rigotti A, Krieger M, Hobbs HH (1996) Regulation of scavenger receptor, class B, type I, a high density lipoprotein receptor, in liver and steroidogenic tissues of the rat. J Clin Invest 98:984-995. https://doi.org/10.1172/ JCI118883

107. Larsson M, Vorrsjo E, Talmud P, Lookene A, Olivecrona G (2013) Apolipoproteins C-I and C-III inhibit lipoprotein lipase activity by displacement of the enzyme from lipid droplets. J Biol Chem 288:33997-34008. https://doi.org/10.1074/jbc. M113.495366

108. Lee J, Jung S, Kim N, Shin MJ, Ryu DH, Hwang GS (2017) Myocardial metabolic alterations in mice with diet-induced atherosclerosis: linking sulfur amino acid and lipid metabolism. Sci Rep 7:13597. https://doi.org/10.1038/s41598-01713991-z

109. Lefebvre P, Cariou B, Lien F, Kuipers F, Staels B (2009) Role of bile acids and bile acid receptors in metabolic regulation. Physiol Rev 89:147-191. https://doi.org/10.1152/physrev.00010.2008

110. Leigh SE, Foster AH, Whittall RA, Hubbart CS, Humphries SE (2008) Update and analysis of the University College London low density lipoprotein receptor familial hypercholesterolemia database. Ann Hum Genet 72:485-498. https://doi.org/10.111 1/j.1469-1809.2008.00436.x

111. Leppanen P, Luoma JS, Hofker MH, Havekes LM, Yla-Herttuala $S$ (1998) Characterization of atherosclerotic lesions in apo E3-leiden transgenic mice. Atherosclerosis 136:147-152. https ://doi.org/10.1016/s0021-9150(97)00196-2

112. Li G, Tokuno S, Tahep ld P, Vaage J, Lowbeer C, Valen G (2001) Preconditioning protects the severely atherosclerotic mouse heart. Ann Thorac Surg 71:1296-1303. https://doi.org/10.1016/ s0003-4975(00)02608-4

113. Li H, Forstermann U (2000) Nitric oxide in the pathogenesis of vascular disease. J Pathol 190:244-254. https://doi. org/10.1002/(SICI)1096-9896(200002)190:3\%3c244::AIDPATH575\%3e3.0.CO;2-8

114. Li H, Forstermann U (2009) Prevention of atherosclerosis by interference with the vascular nitric oxide system. Curr Pharm Des 15:3133-3145. https://doi.org/10.2174/138161209789058 002

115. Liao J, Guo X, Wang M, Dong C, Gao M, Wang H, Kayoumu A, Shen Q, Wang Y, Wang F, Huang W, Liu G (2017) Scavenger receptor class $\mathrm{B}$ Type 1 deletion led to coronary atherosclerosis and ischemic heart disease in low-density lipoprotein receptor knockout mice on modified western-type diet. J Atheroscler Thromb 24:133-146. https://doi.org/10.5551/jat.33019

116. Libby P, Buring JE, Badimon L, Hansson GK, Deanfield J, Bittencourt MS, Tokgozoglu L, Lewis EF (2019) Atherosclerosis. Nat Rev Dis Primers 5:56. https://doi.org/10.1038/s4157 2-019-0106-Z

117. Libby P, Ridker PM, Hansson GK (2011) Progress and challenges in translating the biology of atherosclerosis. Nature 473:317-325. https://doi.org/10.1038/nature10146

118. Lim SS, Vos T, Flaxman AD, Danaei G, Shibuya K, AdairRohani H, Amann M, Anderson HR, Andrews KG, Aryee M, Atkinson C, Bacchus LJ, Bahalim AN, Balakrishnan K, Balmes J, Barker-Collo S, Baxter A, Bell ML, Blore JD, Blyth F, Bonner C, Borges G, Bourne R, Boussinesq M, Brauer M, Brooks P, Bruce NG, Brunekreef B, Bryan-Hancock C, Bucello C, Buchbinder R, Bull F, Burnett RT, Byers TE, Calabria B, Carapetis J, Carnahan E, Chafe Z, Charlson F, Chen H, Chen JS, Cheng AT, Child JC, Cohen A, Colson KE, Cowie BC, Darby S, Darling S, Davis A, Degenhardt L, Dentener F, Des Jarlais DC, Devries K, Dherani M, Ding EL, Dorsey ER, Driscoll T, Edmond K, Ali SE, Engell RE, Erwin PJ, Fahimi S, Falder G, Farzadfar F, Ferrari A, Finucane MM, Flaxman S, Fowkes FG, Freedman G, Freeman MK, Gakidou E, Ghosh S, Giovannucci E, Gmel G, Graham K, 
Grainger R, Grant B, Gunnell D, Gutierrez HR, Hall W, Hoek HW, Hogan A, Hosgood HD 3rd, Hoy D, Hu H, Hubbell BJ, Hutchings SJ, Ibeanusi SE, Jacklyn GL, Jasrasaria R, Jonas JB, Kan H, Kanis JA, Kassebaum N, Kawakami N, Khang YH, Khatibzadeh S, Khoo JP, Kok C, Laden F et al (2012) A comparative risk assessment of burden of disease and injury attributable to 67 risk factors and risk factor clusters in 21 regions, 1990-2010: a systematic analysis for the Global Burden of Disease Study 2010. Lancet 380:2224-2260. https://doi.org/10.1016/S0140 $-6736(12) 61766-8$

119. Lim VG, Bell RM, Arjun S, Kolatsi-Joannou M, Long DA, Yellon DM (2019) SGLT2 inhibitor, canagliflozin, attenuates myocardial infarction in the diabetic and nondiabetic heart. JACC Basic Transl Sci 4:15-26. https://doi.org/10.1016/j.jacbt s.2018.10.002

120. Liu P, Xu B, Cavalieri TA, Hock CE (2002) Age-related difference in myocardial function and inflammation in a rat model of myocardial ischemia-reperfusion. Cardiovasc Res 56:443-453. https://doi.org/10.1016/s0008-6363(02)00603-x

121. Llorente-Cortes V, Martinez-Gonzalez J, Badimon L (2000) LDL receptor-related protein mediates uptake of aggregated LDL in human vascular smooth muscle cells. Arterioscler Thromb Vasc Biol 20:1572-1579. https://doi.org/10.1161/01.atv.20.6.1572

122. Lonborg J, Vejlstrup N, Kelbaek H, Botker HE, Kim WY, Mathiasen AB, Jorgensen E, Helqvist S, Saunamaki K, Clemmensen P, Holmvang L, Thuesen L, Krusell LR, Jensen JS, Kober L, Treiman M, Holst JJ, Engstrom T (2012) Exenatide reduces reperfusion injury in patients with ST-segment elevation myocardial infarction. Eur Heart J 33:1491-1499. https:// doi.org/10.1093/eurheartj/ehr309

123. Ludmer PL, Selwyn AP, Shook TL, Wayne RR, Mudge GH, Alexander RW, Ganz P (1986) Paradoxical vasoconstriction induced by acetylcholine in atherosclerotic coronary arteries. N Engl J Med 315:1046-1051. https://doi.org/10.1056/NEJM1 98610233151702

124. Lutgens E, Daemen M, Kockx M, Doevendans P, Hofker M, Havekes L, Wellens H, de Muinck ED (1999) Atherosclerosis in $\mathrm{APOE}^{*} 3$-Leiden transgenic mice: from proliferative to atheromatous stage. Circulation 99:276-283. https://doi. org/10.1161/01.cir.99.2.276

125. Ma Y, Wang W, Zhang J, Lu Y, Wu W, Yan H, Wang Y (2012) Hyperlipidemia and atherosclerotic lesion development in Ldlr-deficient mice on a long-term high-fat diet. PLoS ONE 7:e35835. https://doi.org/10.1371/journal.pone.0035835

126. Maeda N, Johnson L, Kim S, Hagaman J, Friedman M, Reddick R (2007) Anatomical differences and atherosclerosis in apolipoprotein E-deficient mice with 129/SvEv and C57BL/6 genetic backgrounds. Atherosclerosis 195:75-82. https://doi. org/10.1016/j.atherosclerosis.2006.12.006

127. Mahley RW, Innerarity TL (1983) Lipoprotein receptors and cholesterol homeostasis. Biochim Biophys Acta 737:197-222. https://doi.org/10.1016/0304-4157(83)90001-1

128. Mahley RW, Rall SC Jr (2000) Apolipoprotein E: far more than a lipid transport protein. Annu Rev Genomics Hum Genet 1:507-537. https://doi.org/10.1146/annurev.genom.1.1.507

129. Marino A, Zhang Y, Rubinelli L, Riemma MA, Ip JE, Di Lorenzo A (2019) Pressure overload leads to coronary plaque formation, progression, and myocardial events in ApoE-/- mice. JCI Insight. https://doi.org/10.1172/jci.insight.128220

130. Maxwell KN, Breslow JL (2004) Adenoviral-mediated expression of Pcsk9 in mice results in a low-density lipoprotein receptor knockout phenotype. Proc Natl Acad Sci U S A 101:7100-7105. https://doi.org/10.1073/pnas.0402133101

131. McLaren JE, Michael DR, Ashlin TG, Ramji DP (2011) Cytokines, macrophage lipid metabolism and foam cells: implications for cardiovascular disease therapy. Prog Lipid Res 50:331-347. https://doi.org/10.1016/j.plipres.2011.04.002

132. Mentzer RM Jr, Bartels C, Bolli R, Boyce S, Buckberg GD, Chaitman B, Haverich A, Knight J, Menasche P, Myers ML, Nicolau J, Simoons M, Thulin L, Weisel RD, Investigators ES (2008) Sodium-hydrogen exchange inhibition by cariporide to reduce the risk of ischemic cardiac events in patients undergoing coronary artery bypass grafting: results of the EXPEDITION study. Ann Thorac Surg 85:1261-1270. https://doi. org/10.1016/j.athoracsur.2007.10.054

133. Miettinen HE, Rayburn H, Krieger M (2001) Abnormal lipoprotein metabolism and reversible female infertility in HDL receptor (SR-BI)-deficient mice. J Clin Invest 108:1717-1722. https://doi.org/10.1172/JCI13288

134. Miller YI, Choi SH, Wiesner P, Fang L, Harkewicz R, Hartvigsen K, Boullier A, Gonen A, Diehl CJ, Que X, Montano E, Shaw PX, Tsimikas S, Binder CJ, Witztum JL (2011) Oxidation-specific epitopes are danger-associated molecular patterns recognized by pattern recognition receptors of innate immunity. Circ Res 108:235-248. https://doi.org/10.1161/CIRCR ESAHA.110.223875

135. Miyajima C, Iwaki T, Umemura K, Ploplis VA, Castellino FJ (2018) Characterization of atherosclerosis formation in a murine model of type IIA human familial hypercholesterolemia. Biomed Res Int 2018:1878964. https://doi. org/10.1155/2018/1878964

136. Moore KJ, Freeman MW (2006) Scavenger receptors in atherosclerosis: beyond lipid uptake. Arterioscler Thromb Vasc Biol 26:1702-1711. https://doi.org/10.1161/01.ATV.0000229218 97976.43

137. Moore RE, Kawashiri MA, Kitajima K, Secreto A, Millar JS, Pratico D, Rader DJ (2003) Apolipoprotein A-I deficiency results in markedly increased atherosclerosis in mice lacking the LDL receptor. Arterioscler Thromb Vasc Biol 23:1914-1920. https:// doi.org/10.1161/01.ATV.0000092328.66882.F5

138. Murao K, Terpstra V, Green SR, Kondratenko N, Steinberg D, Quehenberger O (1997) Characterization of CLA-1, a human homologue of rodent scavenger receptor $\mathrm{BI}$, as a receptor for high density lipoprotein and apoptotic thymocytes. J Biol Chem 272:17551-17557. https://doi.org/10.1074/jbc.272.28.17551

139. Nahrendorf M, Swirski FK, Aikawa E, Stangenberg L, Wurdinger T, Figueiredo JL, Libby P, Weissleder R, Pittet MJ (2007) The healing myocardium sequentially mobilizes two monocyte subsets with divergent and complementary functions. J Exp Med 204:3037-3047. https://doi.org/10.1084/jem.20070885

140. Nakashima Y, Plump AS, Raines EW, Breslow JL, Ross R (1994) ApoE-deficient mice develop lesions of all phases of atherosclerosis throughout the arterial tree. Arterioscler Thromb 14:133140. https://doi.org/10.1161/01.atv.14.1.133

141. Naoumova RP, Tosi I, Patel D, Neuwirth C, Horswell SD, Marais AD, van Heyningen C, Soutar AK (2005) Severe hypercholesterolemia in four British families with the D374Y mutation in the PCSK9 gene: long-term follow-up and treatment response. Arterioscler Thromb Vasc Biol 25:2654-2660. https://doi. org/10.1161/01.ATV.0000190668.94752.ab

142. Navab M, Ananthramaiah GM, Reddy ST, Van Lenten BJ, Ansell BJ, Fonarow GC, Vahabzadeh K, Hama S, Hough G, Kamranpour N, Berliner JA, Lusis AJ, Fogelman AM (2004) The oxidation hypothesis of atherogenesis: the role of oxidized phospholipids and HDL. J Lipid Res 45:993-1007. https://doi.org/10.1194/ jlr.R400001-JLR200

143. Navab M, Berliner JA, Subbanagounder G, Hama S, Lusis AJ, Castellani LW, Reddy S, Shih D, Shi W, Watson AD, Van Lenten BJ, Vora D, Fogelman AM (2001) HDL and the inflammatory response induced by LDL-derived oxidized 
phospholipids. Arterioscler Thromb Vasc Biol 21:481-488. https ://doi.org/10.1161/01.atv.21.4.481

144. Newby AC, Zaltsman AB (1999) Fibrous cap formation or destruction-the critical importance of vascular smooth muscle cell proliferation, migration and matrix formation. Cardiovasc Res 41:345-360

145. Niccoli G, Burzotta F, Galiuto L, Crea F (2009) Myocardial noreflow in humans. J Am Coll Cardiol 54:281-292. https://doi. org/10.1016/j.jacc.2009.03.054

146. Nordestgaard BG, Chapman Mj Fau-Humphries SE, Humphries Se Fau-Ginsberg HN, Ginsberg Hn Fau-Masana L, Masana L Fau-Descamps OS, Descamps Os Fau-Wiklund O, Wiklund O Fau-Hegele RA, Hegele Ra Fau-Raal FJ, Raal Fj Fau-Defesche JC, Defesche Jc Fau-Wiegman A, Wiegman A Fau-Santos RD, Santos Rd Fau-Watts GF, Watts Gf Fau-Parhofer KG, Parhofer Kg Fau-Hovingh GK, Hovingh Gk Fau-Kovanen PT, Kovanen Pt Fau-Boileau C, Boileau C Fau-Averna M, Averna M FauBorén J, Borén J Fau-Bruckert E, Bruckert E Fau-Catapano AL, Catapano Al Fau-Kuivenhoven JA, Kuivenhoven Ja Fau-Pajukanta P, Pajukanta P Fau-Ray K, Ray K Fau-Stalenhoef AFH, Stalenhoef Af Fau-Stroes E, Stroes E Fau-Taskinen M-R, Taskinen Mr Fau-Tybjærg-Hansen A, Tybjærg-Hansen A Familial hypercholesterolaemia is underdiagnosed and undertreated in the general population: guidance for clinicians to prevent coronary heart disease: consensus statement of the European Atherosclerosis Society

147. O'Brien KD, Allen MD, McDonald TO, Chait A, Harlan JM, Fishbein D, McCarty J, Ferguson M, Hudkins K, Benjamin CD et al (1993) Vascular cell adhesion molecule-1 is expressed in human coronary atherosclerotic plaques. Implications for the mode of progression of advanced coronary atherosclerosis. $\mathbf{J}$ Clin Invest 92:945-951. https://doi.org/10.1172/JCI116670

148. Oppi S, Luscher TF, Stein S (2019) Mouse models for atherosclerosis research-which is my line? Front Cardiovasc Med 6:46. https://doi.org/10.3389/fcvm.2019.00046

149. Organisation WH (2017)

150. Osipov RM, Bianchi C, Feng J, Clements RT, Liu Y, Robich MP, Glazer HP, Sodha NR, Sellke FW (2009) Effect of hypercholesterolemia on myocardial necrosis and apoptosis in the setting of ischemia-reperfusion. Circulation 120:S22-30. https://doi. org/10.1161/CIRCULATIONAHA.108.842724

151. Ott M, Robertson JD, Gogvadze V, Zhivotovsky B, Orrenius S (2002) Cytochrome c release from mitochondria proceeds by a two-step process. Proc Natl Acad Sci U S A 99:1259-1263. https ://doi.org/10.1073/pnas.241655498

152. Paigen B, Ishida BY, Verstuyft J, Winters RB, Albee D (1990) Atherosclerosis susceptibility differences among progenitors of recombinant inbred strains of mice. Arteriosclerosis 10:316-323. https://doi.org/10.1161/01.atv.10.2.316

153. Paigen B, Morrow A, Brandon C, Mitchell D, Holmes P (1985) Variation in susceptibility to atherosclerosis among inbred strains of mice. Atherosclerosis 57:65-73. https://doi.org/10.1016/00219150(85)90138-8

154. Panizzi P, Swirski FK, Figueiredo JL, Waterman P, Sosnovik DE, Aikawa E, Libby P, Pittet M, Weissleder R, Nahrendorf M (2010) Impaired infarct healing in atherosclerotic mice with Ly6C(hi) monocytosis. J Am Coll Cardiol 55:1629-1638. https:// doi.org/10.1016/j.jacc.2009.08.089

155. Pasupathy S, Air T, Dreyer RP, Tavella R, Beltrame JF (2015) Systematic review of patients presenting with suspected myocardial infarction and nonobstructive coronary arteries. Circulation 131:861-870. https://doi.org/10.1161/CIRCULATIO NAHA.114.011201

156. Pearson JT, Yoshimoto M, Chen YC, Sultani R, Edgley AJ, Nakaoka H, Nishida M, Umetani K, Waddingham MT, Jin HL, Zhang Y, Kelly DJ, Schwenke DO, Inagaki T, Tsuchimochi H,
Komuro I, Yamashita S, Shirai M (2017) Widespread coronary dysfunction in the absence of HDL receptor SR-B1 in an ischemic cardiomyopathy mouse model. Sci Rep 7:18108. https ://doi.org/10.1038/s41598-017-18485-6

157. Pei Y, Chen X, Aboutouk D, Fuller MT, Dadoo O, Yu P, White EJ, Igdoura SA, Trigatti BL (2013) SR-BI in bone marrow derived cells protects mice from diet induced coronary artery atherosclerosis and myocardial infarction. PLoS ONE 8:e72492. https://doi.org/10.1371/journal.pone.0072492

158. Pendse AA, Arbones-Mainar JM, Johnson LA, Altenburg MK, Maeda N (2009) Apolipoprotein E knock-out and knock-in mice: atherosclerosis, metabolic syndrome, and beyond. J Lipid Res 50(Suppl):S178-182. https://doi.org/10.1194/jlr.R800070-JLR20 0

159. Pereira SS, Teixeira LG, Aguilar EC, Matoso RO, Soares FL, Ferreira AV, Alvarez-Leite JI (2012) Differences in adipose tissue inflammation and oxidative status in C57BL/6 and ApoE-/mice fed high fat diet. Anim Sci J 83:549-555. https://doi.org/1 0.1111/j.1740-0929.2011.00982.x

160. Perrino C, Ferdinandy P, Botker HE, Brundel B, Collins P, Davidson SM, den Ruijter HM, Engel FB, Gerdts E, Girao H, Gyongyosi M, Hausenloy DJ, Lecour S, Madonna R, Marber M, Murphy E, Pesce M, Regitz-Zagrosek V, Sluijter JPG, Steffens S, Gollmann-Tepekoylu C, Van Laake LW, Van Linthout S, Schulz R, Ytrehus K (2020) Improving translational research in sex-specific effects of comorbidities and risk factors in ischemic heart disease and cardioprotection: position paper and recommendations of the ESC working group on cellular biology of the heart. Cardiovasc Res. https://doi.org/10.1093/cvr/cvaa155

161. Piedrahita JA, Zhang SH, Hagaman JR, Oliver PM, Maeda N (1992) Generation of mice carrying a mutant apolipoprotein $\mathrm{E}$ gene inactivated by gene targeting in embryonic stem cells. Proc Natl Acad Sci U S A 89:4471-4475. https://doi. org/10.1073/pnas.89.10.4471

162. Pluijmert NJ, den Haan MC, van Zuylen VL, Steendijk P, de Boer HC, van Zonneveld AJ, Fibbe WE, Schalij MJ, Quax PHA, Atsma DE (2019) Hypercholesterolemia affects cardiac function, infarct size and inflammation in APOE*3-Leiden mice following myocardial ischemia-reperfusion injury. PLoS ONE 14:e0217582. https://doi.org/10.1371/journal.pone.02175 82

163. Plump AS, Smith JD, Hayek T, Aalto-Setala K, Walsh A, Verstuyft JG, Rubin EM, Breslow JL (1992) Severe hypercholesterolemia and atherosclerosis in apolipoprotein E-deficient mice created by homologous recombination in ES cells. Cell 71:343-353. https://doi.org/10.1016/0092-8674(92)90362-g

164. Pons S, Hagege A, Fornes P, Gervais M, Giudicelli JF, Richer C (2003) Effects of angiotensin II type 1 receptor blockade in ApoE-deficient mice with post-ischemic heart failure. J Cardiovasc Pharmacol 42:17-23. https://doi.org/10.1097/00005 344-200307000-00003

165. Qiu C, Zhao X, Zhou Q, Zhang Z (2017) High-density lipoprotein cholesterol efflux capacity is inversely associated with cardiovascular risk: a systematic review and meta-analysis. Lipids Health Dis 16:212. https://doi.org/10.1186/s12944-017-0604-5

166. Raffai RL, Hasty AH, Wang Y, Mettler SE, Sanan DA, Linton MF, Fazio S, Weisgraber KH (2003) Hepatocyte-derived ApoE is more effective than non-hepatocyte-derived ApoE in remnant lipoprotein clearance. J Biol Chem 278:11670-11675. https://doi.org/10.1074/jbc.M212873200

167. Reddick RL, Read MS, Brinkhous KM, Bellinger D, Nichols T, Griggs TR (1990) Coronary atherosclerosis in the pig. Induced plaque injury and platelet response. Arteriosclerosis 10:541-550. https://doi.org/10.1161/01.atv.10.4.541

168. Reid MB (1998) Role of nitric oxide in skeletal muscle: synthesis, distribution and functional importance. Acta Physiol Scand 
162:401-409. https://doi.org/10.1046/j.1365-201X.1998.0303f .X

169. Ridker PM, Everett BM, Thuren T, MacFadyen JG, Chang WH, Ballantyne C, Fonseca F, Nicolau J, Koenig W, Anker SD, Kastelein JJP, Cornel JH, Pais P, Pella D, Genest J, Cifkova R, Lorenzatti A, Forster T, Kobalava Z, Vida-Simiti L, Flather M, Shimokawa H, Ogawa H, Dellborg M, Rossi PRF, Troquay RPT, Libby P, Glynn RJ, Grawup CT (2017) Antiinflammatory therapy with Canakinumab for atherosclerotic disease. N Engl J Med 377:1119-1131. https://doi.org/10.1056/NEJMoa1707914

170. Rigotti A, Trigatti BL, Penman M, Rayburn H, Herz J, Krieger M (1997) A targeted mutation in the murine gene encoding the high density lipoprotein (HDL) receptor scavenger receptor class B type I reveals its key role in HDL metabolism. Proc Natl Acad Sci U S A 94:12610-12615. https://doi.org/10.1073/ pnas.94.23.12610

171. Ritskes-Hoitinga J, Beynen AC (1988) Atherosclerosis in the rat. Artery 16:25-50

172. Roche-Molina M, Sanz-Rosa D, Cruz FM, Garcia-Prieto J, Lopez S, Abia R, Muriana FJ, Fuster V, Ibanez B, Bernal JA (2015) Induction of sustained hypercholesterolemia by single adeno-associated virus-mediated gene transfer of mutant hPCSK9. Arterioscler Thromb Vasc Biol 35:50-59. https://doi. org/10.1161/ATVBAHA.114.303617

173. Rosenfeld ME, Polinsky P, Virmani R, Kauser K, Rubanyi G, Schwartz SM (2000) Advanced atherosclerotic lesions in the innominate artery of the ApoE knockout mouse. Arterioscler Thromb Vasc Biol 20:2587-2592. https://doi.org/10.1161/01. atv.20.12.2587

174. Ross R (1995) Cell biology of atherosclerosis. Annu Rev Physiol 57:791-804. https://doi.org/10.1146/annurev.ph.57.03019 5.004043

175. Ross R (1986) The pathogenesis of atherosclerosis-an update. N Engl J Med 314:488-500. https://doi.org/10.1056/NEJM1 98602203140806

176. Rossello X, Yellon DM (2016) Cardioprotection: the disconnect between bench and bedside. Circulation 134:574-575. https://doi.org/10.1161/CIRCULATIONAHA.116.022829

177. Russell A, Watts S (2000) Vascular reactivity of isolated thoracic aorta of the C57BL/6J mouse. J Pharmacol Exp Ther 294:598-604

178. Saddar S, Carriere V, Lee WR, Tanigaki K, Yuhanna IS, Parathath S, Morel E, Warrier M, Sawyer JK, Gerard RD, Temel RE, Brown JM, Connelly M, Mineo C, Shaul PW (2013) Scavenger receptor class B type I is a plasma membrane cholesterol sensor. Circ Res 112:140-151. https://doi.org/10.1161/CIRCR ESAHA.112.280081

179. Saddar S, Mineo C, Shaul PW (2010) Signaling by the highaffinity HDL receptor scavenger receptor B type I. Arterioscler Thromb Vasc Biol 30:144-150. https://doi.org/10.1161/ ATVBAHA.109.196170

180. Sanchez T (2016) Sphingosine-1-phosphate signaling in endothelial disorders. Curr Atheroscler Rep 18:31. https://doi. org/10.1007/s11883-016-0586-1

181. Schaper J, Schaper W (1988) Time course of myocardial necrosis. Cardiovasc Drugs Ther 2:17-25. https://doi.org/10.1007/ BF00054248

182. Sehayek E, Ono JG, Duncan EM, Batta AK, Salen G, Shefer S, Neguyen LB, Yang K, Lipkin M, Breslow JL (2001) Hyodeoxycholic acid efficiently suppresses atherosclerosis formation and plasma cholesterol levels in mice. J Lipid Res 42:1250-1256

183. Sen T, Astarcioglu MA, Beton O, Asarcikli LD, Kilit C (2017) Which coronary lesions are more prone to cause acute myocardial infarction? Arq Bras Cardiol 108:149-153. https://doi. org/10.5935/abc.20170003
184. Sjoland H, Eitzman DT, Gordon D, Westrick R, Nabel EG, Ginsburg D (2000) Atherosclerosis progression in LDL receptor-deficient and apolipoprotein E-deficient mice is independent of genetic alterations in plasminogen activator inhibitor-1. Arterioscler Thromb Vasc Biol 20:846-852. https://doi. org/10.1161/01.atv.20.3.846

185. Skold BH, Getty R, Ramsey FK (1966) Spontaneous atherosclerosis in the arterial system of aging swine. Am J Vet Res 27:257-273

186. Stang1 H, Cao G, Wyne KL, Hobbs HH (1998) Scavenger receptor, class $\mathrm{B}$, type I-dependent stimulation of cholesterol esterification by high density lipoproteins, low density lipoproteins, and nonlipoprotein cholesterol. J Biol Chem 273:3100231008. https://doi.org/10.1074/jbc.273.47.31002

187. Stapleton PA, Goodwill AG, James ME, D'Audiffret AC, Frisbee JC (2010) Differential impact of familial hypercholesterolemia and combined hyperlipidemia on vascular wall and network remodeling in mice. Microcirculation 17:47-58. https ://doi.org/10.1111/j.1549-8719.2009.00003.x

188. Stapleton PA, Goodwill AG, James ME, Frisbee JC (2007) Altered mechanisms of endothelium-dependent dilation in skeletal muscle arterioles with genetic hypercholesterolemia. Am J Physiol Regul Integr Comp Physiol 293:R1110-1119. https://doi.org/10.1152/ajpregu.00410.2007

189. Steinberg D, Glass CK, Witztum JL (2008) Evidence mandating earlier and more aggressive treatment of hypercholesterolemia. Circulation 118:672-677. https://doi.org/10.1161/ CIRCULATIONAHA.107.753152

190. Steinl DC, Kaufmann BA (2015) Ultrasound imaging for risk assessment in atherosclerosis. Int J Mol Sci 16:9749-9769. https ://doi.org/10.3390/ijms16059749

191. Stemme S, Faber B, Holm J, Wiklund O, Witztum JL, Hansson GK (1995) T lymphocytes from human atherosclerotic plaques recognize oxidized low density lipoprotein. Proc Natl Acad Sci U S A 92:3893-3897. https://doi.org/10.1073/pnas.92.9.3893

192. Tall AR (1993) Plasma cholesteryl ester transfer protein. J Lipid Res 34:1255-1274

193. Theilmeier G, Schmidt C, Herrmann J, Keul P, Schafers M, Herrgott I, Mersmann J, Larmann J, Hermann S, Stypmann J, Schober O, Hildebrand R, Schulz R, Heusch G, Haude M, von Wnuck LK, Herzog C, Schmitz M, Erbel R, Chun J, Levkau B (2006) High-density lipoproteins and their constituent, sphingosine-1-phosphate, directly protect the heart against ischemia/ reperfusion injury in vivo via the S1P3 lysophospholipid receptor. Circulation 114:1403-1409. https://doi.org/10.1161/CIRCU LATIONAHA.105.607135

194. Thim T, Hagensen MK, Drouet L, Bal Dit Sollier C, Bonneau M, Granada JF, Nielsen LB, Paaske WP, Botker HE, Falk E (2010) Familial hypercholesterolaemic downsized pig with human-like coronary atherosclerosis: a model for preclinical studies. EuroIntervention 6:261-268

195. Totzeck M, Hendgen-Cotta UB, Rassaf T (2017) Nitrite-nitric oxide signaling and cardioprotection. Adv Exp Med Biol 982:335-346. https://doi.org/10.1007/978-3-319-55330-6_18

196. Traupe T, Keller M, Fojtu E, Bhattacharya I, Lang M, Ha HR, Jochum W, Mundy AL, Barton M (2007) Antioxidant activity and sex differences of acute vascular effects of amiodarone in advanced atherosclerosis. J Cardiovasc Pharmacol 50:578-584. https://doi.org/10.1097/FJC.0b013e31814d6674

197. Trigatti B, Rayburn H, Vinals M, Braun A, Miettinen H, Penman M, Hertz M, Schrenzel M, Amigo L, Rigotti A, Krieger M (1999) Influence of the high density lipoprotein receptor SR-BI on reproductive and cardiovascular pathophysiology. Proc Natl Acad Sci U S A 96:9322-9327. https://doi.org/10.1073/pnas.96.16.9322 
198. van de Steeg E, Kleemann R, Jansen HT, van Duyvenvoorde W, Offerman EH, Wortelboer HM, Degroot J (2013) Combined analysis of pharmacokinetic and efficacy data of preclinical studies with statins markedly improves translation of drug efficacy to human trials. J Pharmacol Exp Ther 347:635-644. https://doi. org/10.1124/jpet.113.208595

199. van den Maagdenberg AM, Hofker MH, Krimpenfort PJ, de Bruijn I, van Vlijmen B, van der Boom H, Havekes LM, Frants RR (1993) Transgenic mice carrying the apolipoprotein E3-Leiden gene exhibit hyperlipoproteinemia. J Biol Chem 268:10540-10545

200. Van der Donckt C, Van Herck JL, Schrijvers DM, Vanhoutte G, Verhoye M, Blockx I, Van Der Linden A, Bauters D, Lijnen HR, Sluimer JC, Roth L, Van Hove CE, Fransen P, Knaapen MW, Hervent AS, De Keulenaer GW, Bult H, Martinet W, Herman AG, De Meyer GR (2015) Elastin fragmentation in atherosclerotic mice leads to intraplaque neovascularization, plaque rupture, myocardial infarction, stroke, and sudden death. Eur Heart J 36:1049-1058. https://doi.org/10.1093/eurheartj/ehu041

201. van der Hoorn JW, de Haan W, Berbee JF, Havekes LM, Jukema JW, Rensen PC, Princen HM (2008) Niacin increases HDL by reducing hepatic expression and plasma levels of cholesteryl ester transfer protein in APOE*3Leiden.CETP mice. Arterioscler Thromb Vasc Biol 28:2016-2022. https://doi.org/10.1161/ ATVBAHA.108.171363

202. van der Worp HB, Howells DW, Sena ES, Porritt MJ, Rewell S, O'Collins V, Macleod MR (2010) Can animal models of disease reliably inform human studies? PLoS Med 7:e1000245. https:// doi.org/10.1371/journal.pmed.1000245

203. Van Eck M, Twisk J, Hoekstra M, Van Rij BT, Van der Lans CA, Bos IS, Kruijt JK, Kuipers F, Van Berkel TJ (2003) Differential effects of scavenger receptor BI deficiency on lipid metabolism in cells of the arterial wall and in the liver. J Biol Chem 278:2369923705. https://doi.org/10.1074/jbc.M211233200

204. Van Herck JL, De Meyer GR, Martinet W, Van Hove CE, Foubert K, Theunis MH, Apers S, Bult H, Vrints CJ, Herman AG (2009) Impaired fibrillin-1 function promotes features of plaque instability in apolipoprotein E-deficient mice. Circulation 120:24782487. https://doi.org/10.1161/CIRCULATIONAHA.109.87266 3

205. van Vlijmen BJ, van den Maagdenberg AM, Gijbels MJ, van der Boom H, HogenEsch H, Frants RR, Hofker MH, Havekes LM (1994) Diet-induced hyperlipoproteinemia and atherosclerosis in apolipoprotein E3-Leiden transgenic mice. J Clin Invest 93:1403-1410. https://doi.org/10.1172/JCI117117

206. VanderLaan PA, Reardon CA, Getz GS (2004) Site specificity of atherosclerosis: site-selective responses to atherosclerotic modulators. Arterioscler Thromb Vasc Biol 24:12-22. https:// doi.org/10.1161/01.ATV.0000105054.43931.f0

207. Varban ML, Rinninger F, Wang N, Fairchild-Huntress V, Dunmore JH, Fang Q, Gosselin ML, Dixon KL, Deeds JD, Acton SL, Tall AR, Huszar D (1998) Targeted mutation reveals a central role for SR-BI in hepatic selective uptake of high density lipoprotein cholesterol. Proc Natl Acad Sci U S A 95:4619-4624. https ://doi.org/10.1073/pnas.95.8.4619

208. Vergeer M, Korporaal SJ, Franssen R, Meurs I, Out R, Hovingh GK, Hoekstra M, Sierts JA, Dallinga-Thie GM, Motazacker MM, Holleboom AG, Van Berkel TJ, Kastelein JJ, Van Eck M, Kuivenhoven JA (2011) Genetic variant of the scavenger receptor BI in humans. N Engl J Med 364:136-145. https://doi.org/10.1056/ NEJMoa0907687

209. Verghese PB, Castellano JM, Garai K, Wang Y, Jiang H, Shah A, Bu G, Frieden C, Holtzman DM (2013) ApoE influences amyloid-beta (Abeta) clearance despite minimal apoE/Abeta association in physiological conditions. Proc Natl Acad Sci U S A 110:E1807-1816. https://doi.org/10.1073/pnas.1220484110
210. Vergnes L, Phan J, Strauss M, Tafuri S, Reue K (2003) Cholesterol and cholate components of an atherogenic diet induce distinct stages of hepatic inflammatory gene expression. J Biol Chem 278:42774-42784. https://doi.org/10.1074/jbc.M3060 22200

211. Vesselinovitch D, Wissler RW, Doull J (1968) Experimental production of atherosclerosis in mice. 1. Effect of various synthetic diets and radiation on survival time, food consumption and body weight in mice. J Atheroscler Res 8:483-495. https://doi. org/10.1016/s0368-1319(68)80104-8

212. Vilahur G, Gutierrez M, Casani L, Cubedo J, Capdevila A, Pons-Llado G, Carreras F, Hidalgo A, Badimon L (2015) Hypercholesterolemia abolishes high-density lipoprotein-related cardioprotective effects in the setting of myocardial infarction. $\mathrm{J}$ Am Coll Cardiol 66:2469-2470. https://doi.org/10.1016/j. jacc.2015.08.901

213. Voight BF, Peloso GM, Orho-Melander M, Frikke-Schmidt R, Barbalic M, Jensen MK, Hindy G, Holm H, Ding EL, Johnson T, Schunkert H, Samani NJ, Clarke R, Hopewell JC, Thompson JF, Li M, Thorleifsson G, Newton-Cheh C, Musunuru K, Pirruccello JP, Saleheen D, Chen L, Stewart A, Schillert A, Thorsteinsdottir U, Thorgeirsson G, Anand S, Engert JC, Morgan T, Spertus J, Stoll M, Berger K, Martinelli N, Girelli D, McKeown PP, Patterson CC, Epstein SE, Devaney J, Burnett MS, Mooser V, Ripatti S, Surakka I, Nieminen MS, Sinisalo J, Lokki ML, Perola M, Havulinna A, de Faire U, Gigante B, Ingelsson E, Zeller T, Wild P, de Bakker PI, Klungel OH, Maitland-van der Zee AH, Peters BJ, de Boer A, Grobbee DE, Kamphuisen PW, Deneer VH, Elbers CC, Onland-Moret NC, Hofker MH, Wijmenga C, Verschuren WM, Boer JM, van der Schouw YT, Rasheed A, Frossard P, Demissie S, Willer C, Do R, Ordovas JM, Abecasis GR, Boehnke M, Mohlke KL, Daly MJ, Guiducci C, Burtt NP, Surti A, Gonzalez E, Purcell S, Gabriel S, Marrugat J, Peden J, Erdmann J, Diemert P, Willenborg C, Konig IR, Fischer M, Hengstenberg C, Ziegler A, Buysschaert I, Lambrechts D, Van de Werf F, Fox KA, El Mokhtari NE, Rubin D, Schrezenmeir J, Schreiber S et al (2012) Plasma HDL cholesterol and risk of myocardial infarction: a mendelian randomisation study. Lancet 380:572-580. https://doi.org/10.1016/S0140-6736(12)60312-2

214. von Holt K, Lebrun S, Stinn W, Conroy L, Wallerath T, Schleef R (2009) Progression of atherosclerosis in the Apo E-/- model: 12-month exposure to cigarette mainstream smoke combined with high-cholesterol/fat diet. Atherosclerosis 205:135-143. https://doi.org/10.1016/j.atherosclerosis.2008.11.031

215. Waldecker B, Waas W, Haberbosch W, Voss R, Wiecha J, Tillmanns H (2002) Prevalence and significance of coronary collateral circulation in patients with acute myocardial infarct. Z Kardiol 91:243-248. https://doi.org/10.1007/s003920200018

216. Wang JC, Normand SL, Mauri L, Kuntz RE (2004) Coronary artery spatial distribution of acute myocardial infarction occlusions. Circulation 110:278-284. https://doi.org/10.1161/01. CIR.0000135468.67850.F4

217. Wang N, Arai T, Ji Y, Rinninger F, Tall AR (1998) Liver-specific overexpression of scavenger receptor BI decreases levels of very low density lipoprotein ApoB, low density lipoprotein ApoB, and high density lipoprotein in transgenic mice. J Biol Chem 273:32920-32926. https://doi.org/10.1074/jbc.273.49.32920

218. Weinheimer CJ, Lai L, Kelly DP, Kovacs A (2015) Novel mouse model of left ventricular pressure overload and infarction causing predictable ventricular remodelling and progression to heart failure. Clin Exp Pharmacol Physiol 42:33-40. https://doi. org/10.1111/1440-1681.12318

219. Williams H, Johnson JL, Carson KG, Jackson CL (2002) Characteristics of intact and ruptured atherosclerotic plaques in brachiocephalic arteries of apolipoprotein E knockout mice. Arterioscler 
Thromb Vasc Biol 22:788-792. https://doi.org/10.1161/01. atv.0000014587.66321.b4

220. Wilson C, Mau T, Weisgraber KH, Wardell MR, Mahley RW, Agard DA (1994) Salt bridge relay triggers defective LDL receptor binding by a mutant apolipoprotein. Structure 2:713-718. https://doi.org/10.1016/s0969-2126(00)00072-1

221. Wolf D, Ley K (2019) Immunity and inflammation in atherosclerosis. Circ Res 124:315-327. https://doi.org/10.1161/CIRCR ESAHA.118.313591

222. Woo JS, Kim W, Ha SJ, Kim JB, Kim SJ, Kim WS, Seon HJ, Kim KS (2013) Cardioprotective effects of exenatide in patients with ST-segment-elevation myocardial infarction undergoing primary percutaneous coronary intervention: results of exenatide myocardial protection in revascularization study. Arterioscler Thromb Vasc Biol 33:2252-2260. https://doi.org/10.1161/ ATVBAHA.113.301586

223. Xiong Y, Hla T (2014) S1P control of endothelial integrity. Curr Top Microbiol Immunol 378:85-105. https://doi. org/10.1007/978-3-319-05879-5_4

224. Xu XP, Meisel SR, Ong JM, Kaul S, Cercek B, Rajavashisth TB, Sharifi B, Shah PK (1999) Oxidized low-density lipoprotein regulates matrix metalloproteinase- 9 and its tissue inhibitor in human monocyte-derived macrophages. Circulation 99:993-998. https://doi.org/10.1161/01.cir.99.8.993

225. Yanni AE (2004) The laboratory rabbit: an animal model of atherosclerosis research. Lab Anim 38:246-256. https://doi. org/10.1258/002367704323133628

226. Yla-Herttuala S, Bentzon JF, Daemen M, Falk E, Garcia-Garcia HM, Herrmann J, Hoefer I, Jukema JW, Krams R, Kwak BR, Marx N, Naruszewicz M, Newby A, Pasterkamp G, Serruys PW, Waltenberger J, Weber C, Tokgozoglu L (2011) Stabilisation of atherosclerotic plaques. Position paper of the European Society of Cardiology (ESC) Working Group on atherosclerosis and vascular biology. Thromb Haemost 106:1-19. https://doi. org/10.1160/TH10-12-0784

227. You P, Hu H, Chen Y, Zhao Y, Yang Y, Wang T, Xing R, Shao Y, Zhang W, Li D, Chen H, Liu M (2016) Effects of melanocortin 3 and 4 receptor deficiency on energy homeostasis in rats. Sci Rep 6:34938. https://doi.org/10.1038/srep34938

228. You Y, Liu W, Li Y, Zhang Y, Li D, Li W, Yin X, Liao F, Zhu $X$, Liu C (2011) Joint preventive effects of swimming and Shenlian extract on rat atherosclerosis. Clin Hemorheol Microcirc 47:187-198. https://doi.org/10.3233/CH-2010-1380

229. Yu LM, Yang G, Zhang XJ, Wang P, Weng XY, Yang YY, Li ZL, Fang MM, Xu Y, Sun AJ, Ge JB (2018) Megakaryocytic leukemia 1 (MKL1) bridges epigenetic activation of NADPH oxidase in macrophages to cardiac ischemia-reperfusion injury. Circulation

230. Yusuf S, Hawken S, Ounpuu S, Dans T, Avezum A, Lanas F, McQueen M, Budaj A, Pais P, Varigos J, Lisheng L, Investigators IS (2004) Effect of potentially modifiable risk factors associated with myocardial infarction in 52 countries (the INTERHEART study): case-control study. Lancet 364:937-952. https://doi. org/10.1016/S0140-6736(04)17018-9

231. Zadelaar S, Kleemann R, Verschuren L, de Vries-Van der Weij J, van der Hoorn J, Princen HM, Kooistra T (2007) Mouse models for atherosclerosis and pharmaceutical modifiers. Arterioscler Thromb Vasc Biol 27:1706-1721. https://doi.org/10.1161/ ATVBAHA.107.142570

232. Zaid A, Roubtsova A, Essalmani R, Marcinkiewicz J, Chamberland A, Hamelin J, Tremblay M, Jacques H, Jin W, Davignon J, Seidah NG, Prat A (2008) Proprotein convertase subtilisin/kexin type 9 (PCSK9): hepatocyte-specific low-density lipoprotein receptor degradation and critical role in mouse liver regeneration. Hepatology 48:646-654. https://doi.org/10.1002/hep.22354

233. Zhang S, Picard MH, Vasile E, Zhu Y, Raffai RL, Weisgraber KH, Krieger M (2005) Diet-induced occlusive coronary atherosclerosis, myocardial infarction, cardiac dysfunction, and premature death in scavenger receptor class B type I-deficient, hypomorphic apolipoprotein ER61 mice. Circulation 111:3457-3464. https://doi.org/10.1161/CIRCULATIONAHA.104.523563

234. Zhao Y, Yang Y, Xing R, Cui X, Xiao Y, Xie L, You P, Wang T, Zeng L, Peng W, Li D, Chen H, Liu M (2018) Hyperlipidemia induces typical atherosclerosis development in Ldlr and Apoe deficient rats. Atherosclerosis 271:26-35. https://doi. org/10.1016/j.atherosclerosis.2018.02.015

235. Zhao Y, Ye D, Wang J, Calpe-Berdiel L, Azzis SB, Van Berkel TJ, Van Eck M (2011) Stage-specific remodeling of atherosclerotic lesions upon cholesterol lowering in LDL receptor knockout mice. Am J Pathol 179:1522-1532. https://doi.org/10.1016/j. ajpath.2011.05.020

236. Zhou J, Moller J, Danielsen CC, Bentzon J, Ravn HB, Austin RC, Falk E (2001) Dietary supplementation with methionine and homocysteine promotes early atherosclerosis but not plaque rupture in ApoE-deficient mice. Arterioscler Thromb Vasc Biol 21:1470-1476. https://doi.org/10.1161/hq0901.096582

237. Zhou Z, Zhang S, Ding S, Abudupataer M, Zhang Z, Zhu X, Zhang W, Zou Y, Yang X, Ge J, Hong T (2019) Excessive neutrophil extracellular trap formation aggravates acute myocardial infarction injury in apolipoprotein E deficiency mice via the ROS-dependent pathway. Oxid Med Cell Longev 2019:1209307. https://doi.org/10.1155/2019/1209307 